\title{
Combining criteria for delineating lahar- and flash-flood-prone hazard and risk zones for the city of Arequipa, Peru
}

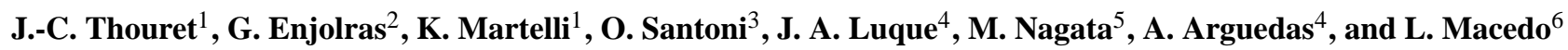 \\ ${ }^{1}$ PRES Clermont, Université Blaise Pascal, Laboratoire Magmas et Volcans, UMR6524 CNRS et IRD-R163, 5 rue Kessler, \\ 63038 Clermont-Ferrand cedex, France \\ ${ }^{2}$ CRET-LOG, Aix-Marseille University, 14 avenue Jules Ferry, 13621 Aix-en-Provence cedex, France \\ ${ }^{3}$ Ceramac, Maison des Sciences de l'Homme, Université Blaise Pascal, 4 rue Ledru, Clermont-Ferrand, France \\ ${ }^{4}$ Defensa Civil Paucarpata and NGO PREDES, Av. Unión Nro. 200, Urb. César Vallejo, Paucarpata, Arequipa, Peru \\ ${ }^{5}$ Departamento de Geografia, Pontifica Universidad Católica de Lima, Av. Universitaria 1801, San Miguel, Lima, Peru \\ ${ }^{6}$ INGEMMET, Instituto Nacional de Geologia, Minero y Metalurgico, Av. Dolores (Urb. Las Begonias B-3), \\ José Luis Bustamante y Rivero, Arequipa, Peru
}

Correspondence to: J.-C. Thouret (j.c.thouret@opgc.univ-bpclermont.fr)

Received: 13 July 2012 - Published in Nat. Hazards Earth Syst. Sci. Discuss.: -

Revised: 28 December 2012 - Accepted: 7 January 2013 - Published: 14 February 2013

\begin{abstract}
Arequipa, the second largest city in Peru, is exposed to many natural hazards, most notably earthquakes, volcanic eruptions, landslides, lahars (volcanic debris flows), and flash floods. Of these, lahars and flash floods, triggered by occasional torrential rainfall, pose the most frequently occurring hazards that can affect the city and its environs, in particular the areas containing low-income neighbourhoods. This paper presents and discusses criteria for delineating areas prone to flash flood and lahar hazards, which are localized along the usually dry (except for the rainy season) ravines and channels of the Río Chili and its tributaries that dissect the city. Our risk-evaluation study is based mostly on field surveys and mapping, but we also took into account quality and structural integrity of buildings, available socioeconomic data, and information gained from interviews with risk-managers officials.

In our evaluation of the vulnerability of various parts of the city, in addition to geological and physical parameters, we also took into account selected socio-economic parameters, such as the educational and poverty level of the population, unemployment figures, and population density. In addition, we utilized a criterion of the "isolation factor", based on distances to access emergency resources (hospitals, shelters or safety areas, and water) in each city block. By combining the hazard, vulnerability and exposure criteria, we produced detailed risk-zone maps at the city-block scale, cov-
\end{abstract}

ering the whole city of Arequipa and adjacent suburbs. Not surprisingly, these maps show that the areas at high risk coincide with blocks or districts with populations at low socioeconomic levels. Inhabitants at greatest risk are the poor recent immigrants from rural areas who live in unauthorized settlements in the outskirts of the city in the upper parts of the valleys. Such settlements are highly exposed to natural hazards and have little access to vital resources.

Our study provides good rationale for the risk zoning of the city, which in turn may be used as an educational tool for better understanding the potential effects of natural hazards and the exposure of the population residing in and around Arequipa. We hope that our work and the risk-zonation maps will provide the impetus and basis for risk-management authorities of the Municipality and the regional government of Arequipa to enforce existing regulations in building in hazardous zones and to adopt an effective long-term strategy to reduce risks from lahar, flash flood, and other natural hazards.

\section{Introduction}

Volcanoes can pose potential severe hazards to nearby cities. Cities such as Naples in Italy (Rolandi, 2010), Arequipa in Peru (Thouret et al., 2001; Vargas-Franco et al., 2010), 
Ibagué in Colombia (Thouret and Laforge, 1994; Künzler et al., 2012) and Yogyakarta in Indonesia (Lavigne, 1999) are all located in vulnerable zones as urbanization encroaches the slopes of their nearby volcanoes. During a large eruption, pyroclastic flows, surges, and heavy tephra fall represent immediate and substantial hazards. Perhaps equally hazardous are the secondary lahars (volcanic debris flows) and flash floods triggered by heavy rainstorms, because they can threaten the populations even when the volcano is quiescent (Thouret, 2002).

The city of Arequipa, southern Peru, is representative of a population centre exposed to volcano-related hazards. Although the last eruption of El Misti volcano occurred during the 15th Century, the volcano still represents a potential threat to the local population. Because of its hazardous setting, scientists have studied the basin area of the city and its neighbouring El Misti volcano in recent decades. Among catastrophic volcanic hazards, heavy rainfall and associated floods affect the city once to twice per decade. Risk-management institutions including Civil Protection authorities and public institutes such as INGEMMET (Instituto Geológico Minero y Metalúrgico) and CISMID (Centro de Investigación Sismológica y de Mitigación de Desastres) have produced hazard-zone maps (e.g. Mariño et al., 2007; Macedo, 2012). However, given the demographic pressures to encroach the slopes of the volcano, it is necessary to transform such documents into risk maps.

The aim of this paper is therefore to delineate lahar- and flash flood-prone risk zones in the city of Arequipa (Peru) by defining a set of criteria for outlining zones vulnerable to these hazards. Such work has two applications (Mechler, 2004): (1) with respect to risk evaluation, maps can outline the areas that could be damaged. They can be used to improve the urban management planning of Arequipa. (2) With respect to risk management, the knowledge of mapped areas allows for preparation for floods and lahars, by diffusing information, preparing evacuations and recovery. Thus, the mapping provides strong support to Civil Protection for mitigating casualties and damage and also for recovery, thus promoting resiliency (Hollnagel, 1996).

Evaluating natural risk requires considering both hazard and vulnerability (Blaikie et al., 2004; Schneiderbauer and Ehrlich, 2004). A hazard is the occurrence of a natural phenomenon of a given magnitude and frequency. This general definition is commonly accepted, although each type of hazard needs to be parameterized according to the context (Smith and Petley, 2009). For example, lahar risk is first studied across a spectrum of hazards, i.e. the characteristics of flows measured by parameters such as volume, height, velocity and density, modulated by the return period (Vallance, 2000). Vulnerability encompasses the foreseeable consequences of hazards on people and the assets to be affected by any given hazardous phenomenon (Künzler et al., 2012). Determining potential losses requires identifying the key factors which generate vulnerability. However, published lit- erature indicates that this question remains open (Cutter et al., 2003; Hufschmidt et al., 2005). According to Künzler et al. (2012), two concepts of vulnerability need to be taken into account: (1) the physical vulnerability related to the sensitivity of elements at risk, for instance people, buildings and facilities; and (2) the socio-economic vulnerability correlated to the ability of the society to cope with hazards. The latter indicator must take into account both the structure and the organization of the society, which includes a person's exposure to hazards and the relief organization.

Over the years, some aspects of lahar hazards and risks have been well studied in the city of Arequipa, focusing on some of their components. Modelling lahar hazards at the citywide scale has been undertaken by Vargas-Franco et al. (2010) and Martelli (2011). The challenge is to obtain more precise information at the scale of a district or block within the city. In such cases, the evaluation of vulnerability is much more complex because it is constrained by the amount and quality of data. Physical vulnerability of buildings has led to a classification of buildings according to their resistance to lahars and floods (Martelli et al., 2010; Martelli, 2011). Without neglecting the above-mentioned parameters, the analysis is focused on the evaluation of socio-economic vulnerability in Arequipa. Due to the lack of consensus in literature, the main challenge is to determine the relevant parameters that will emphasize the specificity of the local vulnerability (Keys, 2007). In addition to a selection of relevant socio-economic indicators such as level of education and employment, the access to key facilities for the effective management of crises is accounted for (De La CruzReyna et al., 2000). Exposure to natural hazards is directly linked to the isolation from strategic resources and supply chains (D'Ercole and Metzger, 2004; Peck, 2006). Therefore, a main point of this paper is to assess vulnerability as a function of the distance between each city block and resource elements such as hospitals, fire stations, water tanks and "safe" areas.

Using a large set of variables related to hazard and vulnerability, a map of lahar risk was drawn for the city of Arequipa considering these two components on an equal basis. Information from this document is provided at the block scale; thus it can be used at the district level without loss of information. Our study has been carried out with two purposes: (1) for the case study of the city of Arequipa, the maps provided in this study may help to mitigate the social and economic consequences from future lahar and flash flood events in the city; and (2) to describe our methodology for other cities exposed to similar risks.

This paper will (1) depict the setting and exposure of Arequipa, focusing on the natural hazards posed to the city at the foot of an active volcano; (2) present data and methods used for this research project; (3) evaluate lahar and flood hazard in Arequipa; (4) discuss criteria for assessing overall vulnerability in the city; and (5) outline risk areas, including 
implications for risk management. The concluding remarks will provide a few recommendations.

\section{Study area: the city of Arequipa}

Arequipa, the second largest city in Peru, is one of the major commercial and tourism centres in the country. Like many South American cities, its recent economic and demographic growth is very dynamic (Pinto da Cunha, 2002). Its GDP grew by $66 \%$ between 2003 and 2008, exceeding $9 \%$ each year, which is the highest rate among Latin American cities (González and Díaz, 2008). The general extent of Arequipa has grown considerably $(+400 \%)$ since 1960 because of a massive influx of people from rural areas, civil unrest and violence in the 1990s, and due to flourishing economic activities. Over the past four decades, the built area has encroached into approximately $70 \%$ of the oasis and its arable, irrigated land (Municipalidad Provincial de Arequipa, 2002). Such a rapid growth over the past $60 \mathrm{yr}$ has generated a fast expansion of the city boundaries, which now encroach on the slopes of Nevado Chachani to the $\mathrm{N}$ and El Misti to the NE (Fig. 1). Today, the population of Arequipa, neighbouring villages in its oasis, and Chiguata (20 km to the ENE) approaches one million habitants: the population has grown from 331843 in 1972 to 821692 inhabitants in 2007, with a resulting population growth rate of approximately $2.5 \%$ per year.

The city site is located within a depression between the western flank of the Western Cordillera of the Central Andes and the Arequipa batholith to the east of the Pacific piedmont. The depression, which encompasses the Río Chili and Río Andamayo valleys, is surrounded by three volcanic edifices: Pichu Pichu, the oldest, to the ESE; the Chachani volcanic complex to the $\mathrm{N}$; and El Misti the youngest composite cone to the NE. The active, fumarolic El Misti (5822 m.a.s.l.) is located approximately $17 \mathrm{~km}$ north-east of the historical city centre at 2300 m.a.s.l. The city is irrigated by the Río Chili, a perennial river from the wetter Altiplano to the $\mathrm{N}$ and NE of the Western Cordillera. The Río Chili valley and adjacent terraces support houses, industries, commercial settlements and sport facilities, contain six bridges, and supply the drinking water for one million inhabitants. Five ravines (locally termed quebradas or torrenteras), which are usually dry but sporadically wet during the December to March rainy season, dissect the city. The major quebradas, which coincide with pilot areas for this study, are Qda. HuarangalPaucarpata (north-eastern suburbs of the city) and Qda. San Lazaro (northern part), which have formed two fans (Fig. 1). These fans and areas located between the volcano flanks and the historical city centre have been mostly urbanized since the 1960s.

Upon arrival, the new migrants often settle in unauthorized locations, without basic services or facilities (drinkable water, electricity), because in principle the valleys and higher slopes are protected from construction. However, there is little living space in a rapidly expanding city and these areas are where the new "illegal" settlements are cropping up. Moreover, many of the migrants have remained in places where they first arrived, even if their housing is located in an area highly exposed to natural hazards, with new neighbourhoods quickly forming and claiming basic services from the City Hall. Except for the sectors located on the fringes of the city, all districts have their own social organization. In many cases, a representative, who has been chosen by the inhabitants, acts as a relay with the civil administration of the city. This delegate knows both the population and the district area well and he/she can then convey information about natural hazard prevention and facilitate evacuation and the relief organization during a crisis.

As a result of increasing urbanization, Arequipa is exposed to four main categories of natural hazard, whose threatening effects are enhanced by poor-quality housing and lack of urban infrastructure. The hazards include (1) frequent earthquakes due to either the subduction zone or active faults crossing the depression. The last major earthquake $\left(M_{\mathrm{w}}=\right.$ 8.4) struck the city on 21 June 2001. (2) Flash floods can occurr in the tributaries of the Río Chili, whose channels are temporarily filled by sporadic flows during the rainy season or after an eruption. Dam-break floods can also result along the Río Chili due to the temporary damming of its upper course or failure of the two-dammed lakes north of El Misti volcano. (3) Lahars (both debris flows and hyperconcentrated flows) can occur during and after an eruption, when the rain or other water remobilizes unconsolidated volcanic debris. Hyperconcentrated streamflows carry predominantly sand and gravel sediments with concentrations between 20 to $60 \%$ by volume and 40 to $80 \%$ by weight. Debris flows are mixtures of solid and fluids $>40 \%$ by volume and $>60 \%$ by weight, which move downstream approximately in unison (Pierson, 2005). Secondary, non-eruption-related lahars can also be triggered by heavy rainstorms on loose debris on the volcano flanks. And (4) despite the most recent (AD 1440-1460) El Misti eruption being a low-magnitude vulcanian event, much more powerful explosive activity has occurred in the past and may occur again, as evidenced by the voluminous ( $\mathrm{VEI} \geq 4$, volume $0.1-1 \mathrm{~km}^{3}$ ) Subplinian and Plinian eruptions in the recent geologic past, which have occurred on average every 4000 to $5000 \mathrm{yr}$ over the past 50000 yr (Thouret et al., 2001; Cobeñas et al., 2012; Harpel et al., 2011).

Figure 2 summarizes the geological hazards that endanger Arequipa. The most exposed areas are located on the slopes of the volcanoes that surround the city (Chachani, north of the airport; and El Misti, north-east of the city) and also along the main valleys (Río Chili, Qda. Huarangal). These areas are geologically unstable because of unconsolidated rocks, characterized by low-bearing capacity deposits and therefore high soil acceleration. In addition, the surface water drainage is accelerated in case of heavy rainfall. 


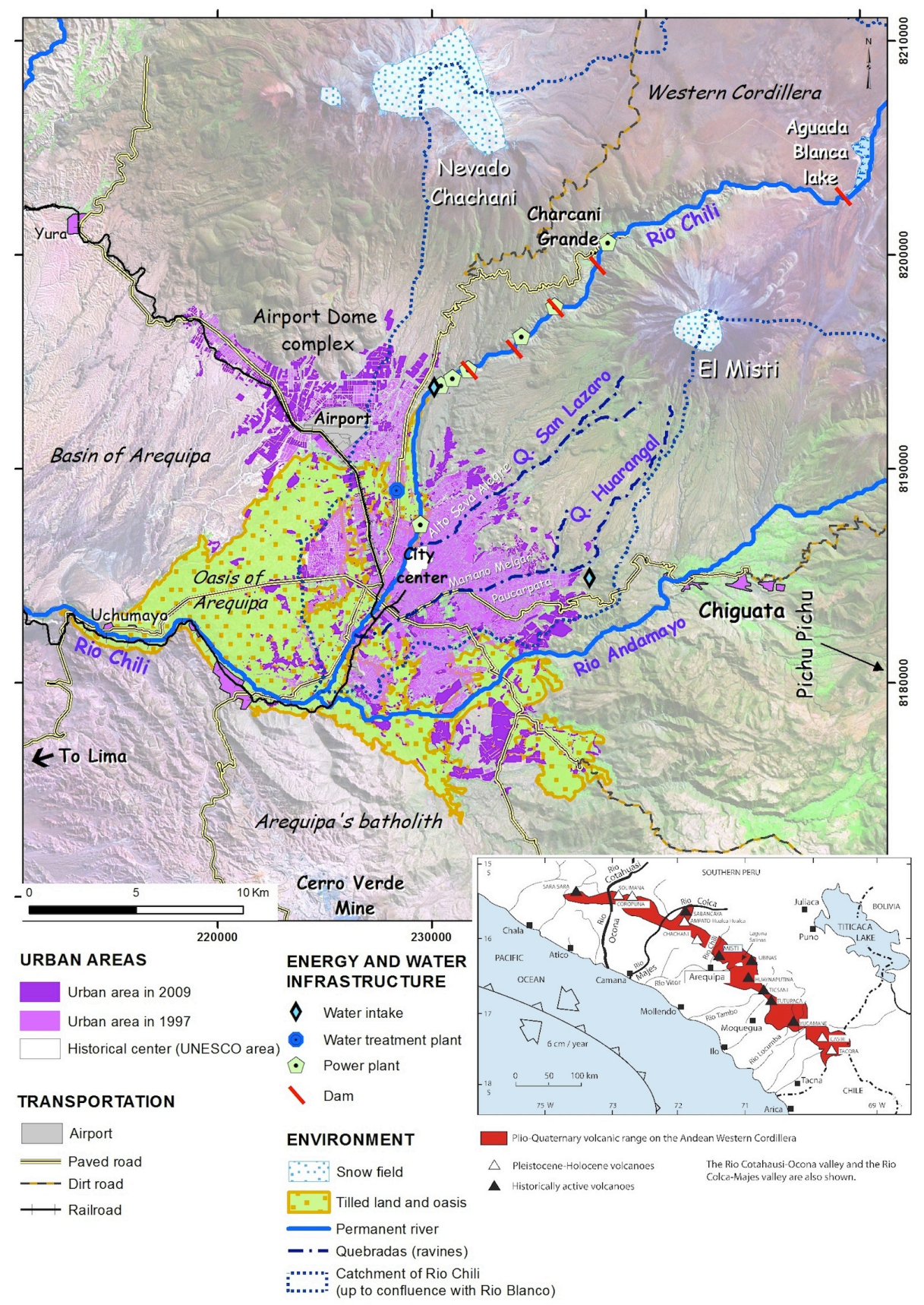

Fig. 1. The setting of Arequipa city in relation to El Misti volcano, showing the volcano, drainage and location of all quoted sites in text.

Lahar frequency and magnitude have been evaluated on the basis of dated deposits in the city area and in archives (newspapers, chronicles and reports). Table 1 shows the lahar frequency according to four types of magnitude. Lahars are infrequent except after eruptions, but flash floods have occurred on average about twice per decade in the otherwise dry environment of Arequipa (average annual rainfall of $150 \mathrm{~mm}$ ). Flash floods and hyperconcentrated flows occurred in 1982, 1989, 1992, 1997 and 2011, claiming only a few victims (3 in 1997) but inflicting sizeable damage on housing, infrastructure and environment. The most recent flash floods occurred between 10 and 16 February 2011 after two weeks of intense rainfall $(126 \mathrm{~mm}$, i.e. three quarters of the average amount of annual rainfall). Three urban areas were partly damaged: the right bank and channel of Qda Huarangal-Mariano Melgar (San Geronimo city block), Alto Selva Alegre (Villa Ecologica city block) and the right bank of Río Chili (Avenida Arancota) down valley 
Table 1. Characteristics of lahars and flash floods in the city of Arequipa (after Martelli, 2011; Vargas-Franco et al., 2010; Delaite et al., 2005; and Thouret et al., 2001).

\begin{tabular}{lllll}
\hline Flow type & $\begin{array}{l}\text { Magnitude } \\
(\text { discharge/volume })\end{array}$ & Frequency & Examples & Comments \\
\hline Flash flood & $\begin{array}{l}260 \mathrm{~m}^{3} \mathrm{~s}^{-1}, \\
2-3 \mathrm{~m} \mathrm{in} \mathrm{height,}^{\text {near city centre }}\end{array}$ & $\begin{array}{l}\text { Once or twice } \\
\text { per decade }\end{array}$ & $\begin{array}{l}\text { Río Chili 1989, 1992; } \\
\text { Qda. Huarangal 1997, 2011 }\end{array}$ & $\begin{array}{l}\text { 5 power supply } \\
\text { and dams built } \\
\text { upstream }\end{array}$ \\
\hline $\begin{array}{l}\text { Hyperconcentrated } \\
\text { streamflow }\end{array}$ & $\begin{array}{l}\text { Low volume } \\
<1.5 \text { million } \mathrm{m}^{3}\end{array}$ & $\begin{array}{l}\text { Once or twice } \\
\text { in a decade }\end{array}$ & Qda Huarangal, 1997 & 3 victims \\
\hline $\begin{array}{l}\text { Lahar: fine-grained, } \\
\text { matrix supported } \\
\text { debris flow }\end{array}$ & $\begin{array}{l}\text { Average volume } \\
>1.5 \text { million } \mathrm{m}^{3}\end{array}$ & $\begin{array}{l}\text { At least once } \\
\text { in 100 yr }\end{array}$ & $\begin{array}{l}\text { Academia Tennis, } \\
\text { Río Chili across } \\
\text { the city centre }\end{array}$ & $\begin{array}{l}\text { Most frequent, } \\
\text { post-eruption or } \\
\text { rain-triggered } \\
\text { lahar type }\end{array}$ \\
\hline $\begin{array}{l}\text { Lahar: coarse, } \\
\text { clast-supported } \\
\text { debris flow }\end{array}$ & $\begin{array}{l}\text { Volume: } 4 \text { to } \\
11 \text { million } \mathrm{m}^{3}\end{array}$ & $\begin{array}{l}\text { At least once } \\
\text { every } 1000 \mathrm{yr}\end{array}$ & $\begin{array}{l}\text { Upper Río Chili } \\
\text { Qda. Huarangal, } \\
\text { Qda. San Lazaro }\end{array}$ & $\begin{array}{l}\text { Contemporaneous } \\
\text { with the eruption } \\
\text { 2030 yr ago }\end{array}$ \\
\hline
\end{tabular}

of Puente Tingo in the south part of the city. According to the regional Civil Protection committee in Arequipa, these flash flood and runoff events ruined 20 houses and damaged about 400 houses located along the quebradas (especially Qda Huarangal) and on steep slopes (Villa Ecologica). However, most damage is indirectly linked to the effects of flash floods due to water impounded by artificial infill obstacles in dry channels, which broke out upstream of the city blocks. The consequences of flash floods directly affect the neighbourhoods located in the valleys but also indirectly affect the whole population. Drinkable water is a scarce resource to which access can be disrupted or impeded by the many hazards (e.g. floods, landslides, earthquakes), even in so-called "safe" areas. Water is stored in two dams located in the upper part of the Río Chili (north of El Misti volcano), and, because of topographic obstacles in the canyon, the transport of drinkable water is not continuous between the storage and the city. The Río Chili canyon becomes a large irrigated alluvial valley only $7 \mathrm{~km}$ upstream of the city centre. The canyon is very vulnerable to landslides and sudden floods; on 8 and 9 February 1989, a sudden flood obstructed water pipes and destroyed segments of the water-distribution network. For 25 days, the city received only $200 \mathrm{~L} \mathrm{~s}^{-1}$ while the usual consumption exceeds $1500 \mathrm{~L} \mathrm{~s}^{-1}$, and as a result the whole population of the city faced drastic water rationing. This example illustrates why an analysis taking account of all components of risk needs to be carried out at the city scale.

\section{Data acquisition and processing}

The quality of information collected for evaluating the risk and its components is critical, and thus data is gathered from three sources. These include (1) land-use planning schemes, whose information is officially distributed; (2) surveys and interviews conducted in the city of Arequipa among institutions and people in charge of risk management; and (3) simulations and evacuation exercises led by Civil Protection and City Hall, considering for instance the occurrence of a flash flood in February 2011 or an earthquake in November 2010.

\subsection{Land-use planning schemes}

Urban planning in Arequipa is constrained by a scheme defined at city scale (Municipalidad Provincial de Arequipa, 2002), taking into account the current land use and providing recommendations for the sustainable development of the city. The urban-development scheme serves as a reference for district-scale construction planning considering natural hazards. The urban scheme contains many maps, which indicate hazards at the city-block scale. However, socio-economic indicators such as literacy and employment rates are scarce and defined only at the local district scale. Moreover, the document does not take into account the "unofficial" development of the city towards the volcano's slopes. Although these areas are designed as unbuildable and requiring "special attention", they have already been built up.

Volcanic and lahar risks result from geologic and hydrologic hazards in the city area of Arequipa, but both categories of risks differ in their origin, their consequences and the ways their effects can be mitigated. Therefore, these two kinds of hazards need to be defined. Following the adoption of the municipal ordinance 658 on 15 November 2010, the volcanic-hazard-zone map published by Mariño et al. (2007), largely based on Thouret et al. (2001), has become an official planning document. Accordingly, the city of Arequipa prevents any construction within the red zones on this map. The red zones correspond to the summit flanks of El Misti volcano and the uppermost reaches of the quebradas, in which "illegal" housing already exists; red zones also extend 


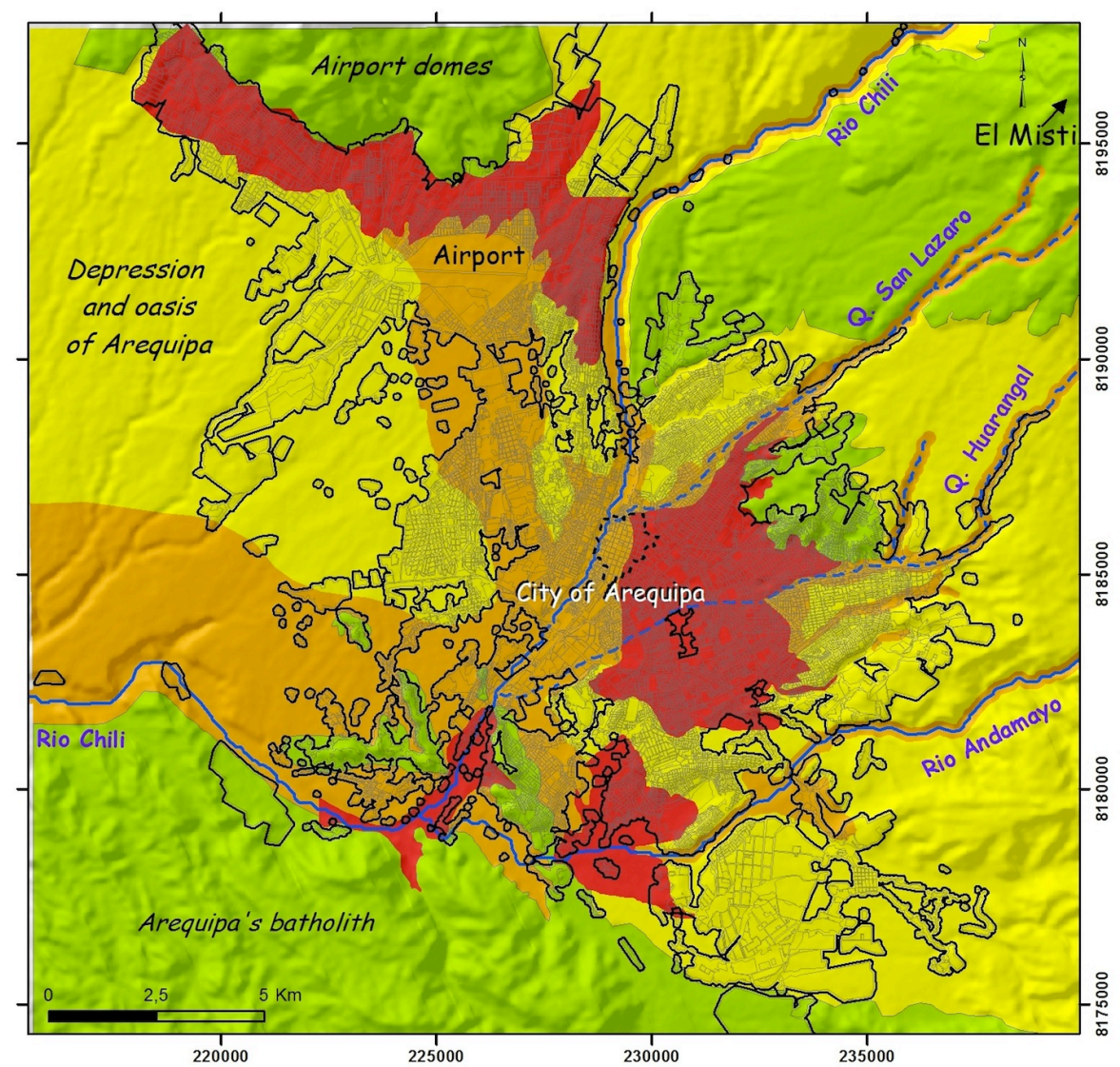

Hazard level (earthquakes, landslides, and linked to bedrock, soils type, water and groundwater)

\begin{tabular}{l} 
Very high hazard High hazard \\
\begin{tabular}{|l|l|l|l|l|}
\hline \multicolumn{1}{|c|}{ Crite ria } & Very high hazard & High hazard & Moderate hazard & Low hazard \\
\hline Soil ac celeration & 0,30 to $0,45 \mathrm{seg}$ & 0,30 to $0,45 \mathrm{seg}$ & 0,20 to $0,30 \mathrm{seg}$ & 0,15 to $0,20 \mathrm{seg}$ \\
\hline Bearing capacity & $<1 \mathrm{~kg} \cdot \mathrm{cm}^{-2}$ & $\begin{array}{l}1<\mathrm{bc}<2{\mathrm{~kg} . \mathrm{cm}^{-2}}^{-2} \\
2<\mathrm{bc}<10 \mathrm{~kg} \cdot \mathrm{cm}^{-2}\end{array}$ & $>10 \mathrm{~kg} \cdot \mathrm{cm}^{-2}$ \\
\hline $\begin{array}{l}\text { Bedrock and } \\
\text { soils }\end{array}$ & $\begin{array}{l}\text { Unconsolidated } \\
\text { rock : alluvium }\end{array}$ & $\begin{array}{l}\text { Unconsolidated } \\
\text { rock : allu vium, sand } \\
\text { and gravel }\end{array}$ & $\begin{array}{l}\text { Unconsolidated } \\
\text { rock : pyroclastic } \\
\text { deposit }\end{array}$ & $\begin{array}{l}\text { Consolidated rock: } \\
\text { lava, granite }\end{array}$ \\
\hline $\begin{array}{l}\text { Water and } \\
\text { ground water }\end{array}$ & $\begin{array}{l}\text { Water at surface : } \\
\text { reservoir or pond }\end{array}$ & $\begin{array}{l}\text { Less than } 5 \mathrm{~m} \text { from } \\
\text { surface }\end{array}$ & More than $5 \mathrm{~m}$ from surface \\
\hline
\end{tabular} \\
\hline
\end{tabular}

Fig. 2. Multi-hazard-zone map of the city of Arequipa showing hazard level (low to very high) for earthquake and landslide, and that related to bedrock, soil type, water and groundwater.

downstream from the volcano along the valleys of the Río Chili and its tributaries. In addition, an official prevention plan to mitigate the effects of heavy rainfall was adopted in 2010 (Municipalidad Provincial de Arequipa, 2010). These mitigation plans, produced by the Municipality of Arequipa Province and the volcanic-hazards map, are examples of official documents that are assumed to be accessible to inhabitants. In practice, however, the map has rarely been disseminated throughout the city. This map only represents ar- eas prone to flooding: it does not depict vulnerable areas and elements at risk. The map lacks explanatory detail, for example, that the quebradas are identified by a colour showing the potential danger and not the actual extents of past flooding.

In summary, the official documents emphasize the hazardous sectors around the volcano but do not consider the vulnerable assets at risk (e.g. houses, bridges, hospitals). At present, there are no official maps that delineate the risks from hazardous processes. In recent years, the official 
documents have been complemented by some expert advice to fulfil some essential requirements, such as identifying the location of water tanks, safety of bridges, and plans for evacuation routes. However, this additional information is not summarized in a unique document or maps that can be accessed, shared, and used by institutions in charge of risk management.

\subsection{Surveys and interviews}

Previous work on lahar and flash flood risk in Arequipa has mainly focused on the assessment of damage to buildings (Martelli et al., 2010). In this study, surveys and interviews were also used to understand how city institutions deal with lahar-risk management from a general point of view. People in charge of risk management in the city of Arequipa can be divided into two groups. (1) Civil Protection representatives from INDECI (Instituto Nacional de Defensa Civil) are involved in risk analysis and emergency planning. They anticipate potential damages and how to overcome them. And (2) representatives of local administrations and companies (i.e. decentralized institutions) who mainly focus on prevention, early warning and communication. This dichotomy in the actions carried out by risk managers can be conspicuous when considering the actions carried out in the districts: while Civil Protection inspects the buildings, INGEMMET organizes simulations for evacuation (Macedo, 2009). These two tasks are complementary and must be incorporated into the mapping of lahar and flash-flood risks.

Interviews have been conducted with ten people in charge of risk management from the six relevant institutions (Table 2): Civil Protection (INDECI) through its national, regional and municipal committees, INGEMMET, City Hall, Department of Arequipa, Region of Arequipa, and SEDAPAR (Servicio de Agua Potable y Alcantarillado de Arequipa). The interviews with city managers were intended to measure their own risk knowledge and perception, while the results indicate how risk zoning is planned and regulation policy is enforced in Arequipa. Semi-directive interviews were conducted in July-August 2010 and in FebruaryMarch 2011 following the most recent flash-flood event, and each interview was complemented by a questionnaire filled out by the risk managers. Managers have been asked to compare lahar risk to other natural risks that may affect the city. They were also asked to provide their own perception of the threats lahars represent for the city. Records of the 2011 crisis were also collected from INDECI and local newspapers, including reports on casualties and damage, as well as the emergency measures used to face the floods and provide support to the affected population.

The results of the interviews (Table 2) indicate that the institution managers are aware of lahar and flood risk but do not consider this issue a priority for Arequipa. According to them, the most important hazards are earthquakes and El Misti eruptions, with flood hazards only in third position.
On 23 June 2001, a large earthquake $\left(M_{\mathrm{w}}=8.4\right)$ hit the region of Arequipa, killing 75 people and damaging at least 50000 homes. However, the frequency of lahars and flash floods in recorded history is much higher than that of earthquakes and volcanic eruptions, but their resulting damage is significantly less. Consequently, the risk managers attach relatively small importance to inundation hazards. Nonetheless, the limited attention attributed by managers to lahar risk belies the tasks performed by Civil Protection and other institutions to anticipate lahar and flood risk.

\subsection{Simulations and evacuation exercises}

The efficacy of risk reduction can be measured through repeated simulations of critical situations, such as a major earthquake. In August and November 2010, simulations were simultaneously carried out at the national scale in Peru, including Arequipa. In addition, programmes regarding flood awareness have been initiated in a few districts of Arequipa where the Civil Protection office is especially involved (Municipalidad Provincial de Arequipa, 2010). Occurrences of actual floods also provide opportunities to measure the effectiveness of the crisis-response system. During the February 2011 flash floods, fire and rescue teams could not reach some neighbourhoods due to the destruction of several roads. The water supply was also damaged and interrupted for one day. In April 2011, people involved in rescue operations could participate in a debriefing with the objective of sharing experiences between Civil Protection and affected people.

\section{Evaluating lahars and floods hazard in Arequipa}

The city of Arequipa has developed entirely on fluvial terraces along the Río Chili valley and on the fans and banks that have been formed by its five tributaries (Quebradas) across the city (Fig. 1). In particular, two alluvial and volcaniclastic fans have been constructed over the past $50 \mathrm{yr}$ : Huarangal-Mariano Melgar to the NE and San Lazaro to the N. Heavy rainfalls affect all quebradas as well as parts of the city located on steep terrain. Water runoff uses natural channels such as the quebradas and some adjacent roads. Runoff is also conveyed through the steep and narrow streets located on the lowermost south-western slopes of El Misti.

Figure 3 shows some examples of damage generated by lahars and mudflows in mid-February 2011 in Río Chili and in Qda. Huarangal. Debris lying on the quebradas beds, from inhabitants dumping garbage and trash, were swept away by the flows. Many constructions located on steep, unstable hill slopes were destroyed or severely damaged by runoff. For the whole city, INDECI reported 629 people injured and 2568 directly affected. As many as 172 houses were destroyed while 576 houses were damaged, mainly in the "illegal" suburbs located on higher slopes to the $\mathrm{N}$ and $\mathrm{NE}$ of the city. A 350-m-long segment of road was destroyed. 


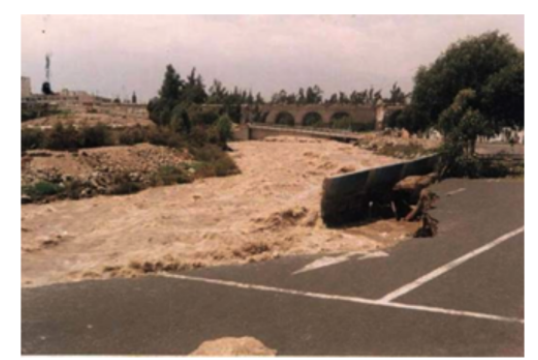

A1. Rio Chili in 1989 (Puente Grau is in the background)

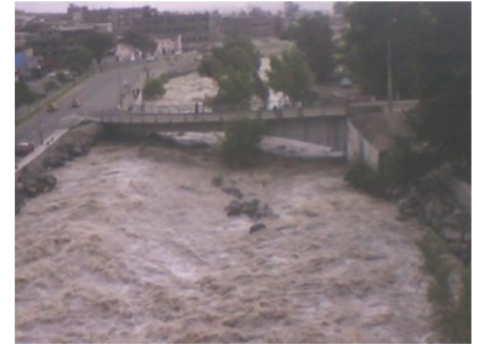

A2. Rio Chili in 2011 (opposite view taken from Puente Grau)

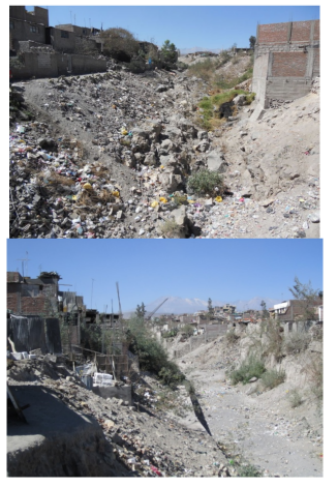

B1. Quebrada Huarangal, Miguel Grau district, in July 2010

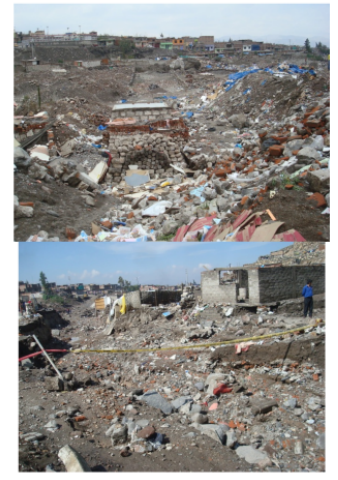

B2. Quebrada Hurangal, Miguel Grau district, just after the early-mid February 2011 floods

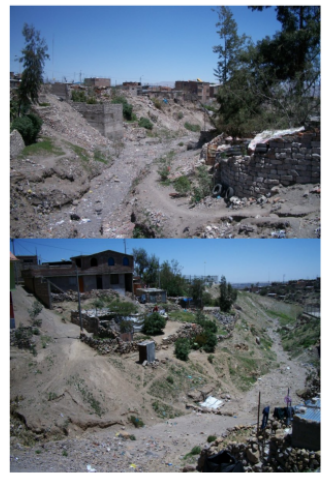

B3. Quebrada Huarangal, Miguel Grau district, in March 2011, one month after the floods

Fig. 3. Pictures showing the Río Chili valley near the city centre (Puente Grau) and Qda. Huarangal in Arequipa (own work). The location of pictures (A) and (B) is provided in Fig. 5.

Fortunately, no one was killed by the flows and no strategic bridges were damaged.

\subsection{Volume and return period of lahars and floods}

Lahar events and deposits include both debris-flow and hyperconcentrated-flow processes. Debris-flow deposits crop out in valleys across Arequipa but cannot be assigned to specific eruptions. The one exception is a pumice-rich lahar deposit linked to pyroclastic-flow deposits produced by the Plinian eruption c. 2030 years BP $\left(1.2 \mathrm{~km}^{3}\right.$ of tephrafall and pyroclastic-flow deposits: Cobeñas et al., 2012). Hyperconcentrated-flow deposits, consisting of sand and gravel beds, are the most abundant and recent (historical and Holocene in age) deposits in the ravines dissecting the city. The relationship between the magnitude and frequency of lahar and flood has been established from the study of lahar and flood deposits preserved within the city area of the Río Chili valley and its tributaries with additional information from the archives (e.g. newspapers, city reports, television footage) (Table 1).

Floods can occur in the Río Chili valley during heavy rainfall: at least nine damaging flood events have been recorded in the past $50 \mathrm{yr}$, e.g. 1961, 1972, 1973, 1989, 1994, 1997,
1999, 2001, and 2011. Other large, historical floods may be due to dam-lake breakouts, as lacustrine deposits underlie terraces in the upper course of the Río Chili valley (in Charcani Grande-Quinto, Fig. 1), suggesting that the upper reach of the canyon was once naturally dammed to form a lake. This prehistoric lake was formed about $2030 \mathrm{yr} \mathrm{BP}\left({ }^{14} \mathrm{C}\right.$, Martelli, 2011) at the time of the last Plinian eruption from El Misti (Harpel et al., 2011; Cobeñas et al., 2012). Flash floods sometimes occur in quebradas, which are normally dry but drain El Misti slopes during the rainy season between November-December and March-April (annual average rainfall of $150 \mathrm{~mm}$ ). Based on a 70-yr-long record, flash floods in the Río Chili tributaries may occur about twice in $10 \mathrm{yr}$ (Fig. 4). Flash floods are triggered by heavy rainstorms that bring 10 to $30 \mathrm{~mm}$ per day to the arid landscape of Arequipa. In the upper catchment of Qda. Huarangal, $33 \mathrm{~mm}$ of rain fell in $3 \mathrm{~h}$ on 25 February 1997, and as much as $126 \mathrm{~mm}$ of rain fell in 10 days in early February 2011, with a maximum of $19.2 \mathrm{~mm} \mathrm{day}^{-1}$. Rainfall may last a few hours over 2 to 5 days during which up to $10 \mathrm{~mm} \mathrm{~h}^{-1}$ fall on dry soil and loose debris in gravel channels or on anthropogenic infill. Unfortunately, these unstable areas are also where poorquality housing is located. 
Table 2. Summary of interviews with institutes, civil authorities and agencies in charge of lahar- and flood-risk management. Each line of the table corresponds to a single interview with a risk manager who compared lahar risk with other risks posed by natural hazards (e.g. volcanic eruptions, earthquakes, landslides, drought and climate change).

\begin{tabular}{|c|c|c|c|c|c|}
\hline Institution & Service & $\begin{array}{l}\text { Role in lahar and } \\
\text { flash flood zoning }\end{array}$ & $\begin{array}{l}\text { Lahar } \\
\text { risk }\end{array}$ & $\begin{array}{l}\text { Lahar } \\
\text { threat }\end{array}$ & $\begin{array}{l}\text { Main tasks performed for } \\
\text { risk management }\end{array}$ \\
\hline INDECI & $\begin{array}{l}\text { Civil Protection } \\
\text { operations }\end{array}$ & $\begin{array}{l}\text { Identification of } \\
\text { at risk areas }\end{array}$ & Fair & $\begin{array}{l}\text { Very } \\
\text { low }\end{array}$ & $\begin{array}{l}\text { Risk analysis, early warning } \\
\text { system, coordination with other } \\
\text { institutions, simulations }\end{array}$ \\
\hline INDECI & $\begin{array}{l}\text { Civil Protection } \\
\text { prevention units }\end{array}$ & $\begin{array}{l}\text { Identification of safe } \\
\text { areas and evacuation } \\
\text { routes }\end{array}$ & Low & Low & $\begin{array}{l}\text { Risk analysis, activation of an } \\
\text { emergency group, estimation of } \\
\text { damages }\end{array}$ \\
\hline Arequipa Region & $\begin{array}{l}\text { Environmental } \\
\text { authority }\end{array}$ & No & High & High & $\begin{array}{l}\text { Coordination with other } \\
\text { institutions }\end{array}$ \\
\hline Arequipa Province & Risk management & $\begin{array}{l}\text { Consulting for the } \\
\text { elaboration of local } \\
\text { management plans }\end{array}$ & Low & Fair & $\begin{array}{l}\text { Simulations, information to the } \\
\text { population }\end{array}$ \\
\hline Arequipa Province & Civil Protection & No & High & Fair & Information to the population \\
\hline Mariano Melgar District & Civil Protection & $\begin{array}{l}\text { Planning at the } \\
\text { district level }\end{array}$ & $\begin{array}{l}\text { Very } \\
\text { high }\end{array}$ & $\begin{array}{l}\text { Very } \\
\text { low }\end{array}$ & $\begin{array}{l}\text { Simulations, information to the } \\
\text { population }\end{array}$ \\
\hline Paucarpata District & Civil Protection & $\begin{array}{l}\text { Evaluation of at } \\
\text { risk areas }\end{array}$ & Fair & Low & $\begin{array}{l}\text { Simulations, information } \\
\text { to the population }\end{array}$ \\
\hline Firemen Corps & Command centre & $\begin{array}{l}\text { Identification of at } \\
\text { risk areas }\end{array}$ & High & Fair & $\begin{array}{l}\text { Risk analysis, emergency } \\
\text { planning and scenarios, } \\
\text { estimation of damages }\end{array}$ \\
\hline INGEMMET & Communication & Creation of risk maps & Fair & High & $\begin{array}{l}\text { Early warning system, } \\
\text { simulations, information } \\
\text { to the population } \\
\text { and the authorities }\end{array}$ \\
\hline SEDAPAR & $\begin{array}{l}\text { Human-resources } \\
\text { management }\end{array}$ & $\begin{array}{l}\text { Identification of } \\
\text { water resources }\end{array}$ & Low & Low & $\begin{array}{l}\text { Information to the engineers } \\
\text { and the authorities }\end{array}$ \\
\hline NGO PREDES & Social promotion & $\begin{array}{l}\text { Identification of safe } \\
\text { and at risk areas }\end{array}$ & $\begin{array}{l}\text { Very } \\
\text { high }\end{array}$ & Fair & $\begin{array}{l}\text { Early warning system, } \\
\text { simulations, information } \\
\text { to the population }\end{array}$ \\
\hline
\end{tabular}

\subsection{Hazards mapping and modelling}

We outline hazard zones along the valley of Río Chili, Qda. San Lazaro and Qda. Hurangal-Mariano Melgar on the basis of the morphology of the floodplains, terraces and fans surrounding the channels. Lahar paths are determined by past lahar flows that have shaped the existing quebradas. The duration and intensity of cumulative precipitation on the El Misti volcano and surrounding mountains, Chachani and Pichu Pichu, will determine the impact of a flood of non-volcanic origin (Vargas-Franco et al., 2010). Factors such as dams or the clearing out of the valley channel can lessen the consequences of a flood. However, other factors may worsen the situation, whether they are permanent (i.e. urbanization of the channels), or temporary (i.e. rock falls or landslips) that can form unstable, natural dams in the Río Chili canyon upstream of the city. Artificial lakes, such as Aguada Blanca and El Frayle, which dam the Río Chili canyon and its tributary Río Blanco north of El Misti (Fig. 1), may also fail in case of an earthquake and landslide. Fortunately, these facilities and infrastructure did not fail during the major earthquake $M_{\mathrm{w}}=8.3$ (USGS) that struck Arequipa, Caraveli, and Moquegua on 23 June 2001.

Our mapping is based on GIS techniques using the results of multidisciplinary studies (Delaite et al., 2005; VargasFranco et al., 2010; Martelli, 2011; Santoni, 2011). Seven stages or terraces have been identified: the channel bed $\mathrm{T} 0$ $(<1 \mathrm{~m}$ above the river) and the terraces $\mathrm{T} 1(2-3 \mathrm{~m}$ high), T1' (3-4 m high), T2 (4-5 m high), T2' (5-10 m high), T3 (10-15 m high) and T4 (15-30 m high). Terraces and fans 


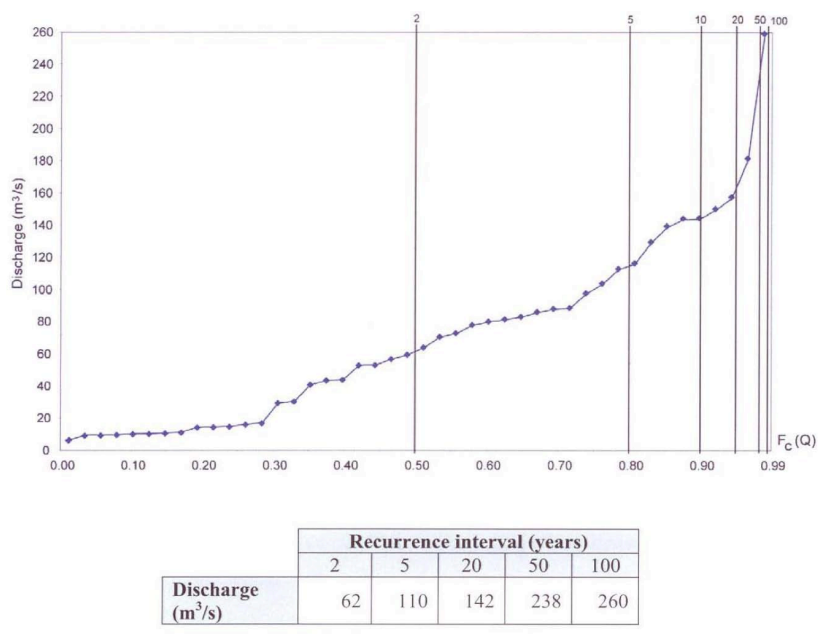

Fig. 4. Adjustment of maximum annual flood for the Río Chili using a Gumbel distribution (after Martelli, 2011). The figure allows us to determine the maximum annual flood discharge and recurrence intervals $(2,5,20,50$ and $100 \mathrm{yr})$ in the Río Chili.

that exceed $30 \mathrm{~m}$ above the valley bottom are not likely to be flooded under the current climatic conditions.

Likely scenarios for flooding and lahars include five hazard severities based on terrace groups as defined in Table 3 and depicted for the whole city of Arequipa in Fig. 5. The terrace groups include the following. (1) The floodplain and T0 of the Río Chili valley ( $\leq 1 \mathrm{~m}$ deep), which are flooded at least once every year in the rainy season: the maximal annual discharge ("normal" river flow) reaches about $50 \mathrm{~m}^{3} \mathrm{~s}^{-1}$, while the average daily discharge can be as low as $10-15 \mathrm{~m}^{3} \mathrm{~s}^{-1}$ (given the fact that discharge is artificially controlled upstream). (2) The T1 terraces are flooded once in 2- to 5-yr time intervals: the river discharge ranges between about 50 and $100 \mathrm{~m}^{3} \mathrm{~s}^{-1}$. The $\mathrm{T} 1$ terraces may also be inundated by lahars whose volume does not exceed 0.5 million $\mathrm{m}^{3}$. (3) The $\mathrm{T} 1$ ' and $\mathrm{T} 2$ terraces are rarely flooded, once in 20 to $50 \mathrm{yr}$ on average. In such circumstances, flood discharge would range between 100 and $150 \mathrm{~m}^{3} \mathrm{~s}^{-1}$, while the lahar average volume would range between 0.5 and 1.5 million $\mathrm{m}^{3}$. (4) The $\mathrm{T} 2$ ' terrace is rarely flooded, with discharges between 230 and $260 \mathrm{~m}^{3} \mathrm{~s}^{-1}$, occurring about once in 50 to $100 \mathrm{yr}$ on average. The T2' terrace would be inundated by large but infrequent dambreakout floods, $10 \mathrm{~m}$ in height, or by lahars whose volume could be 1.5 to 4 million $\mathrm{m}^{3}$ with a $\geq 100$-yr return period (Delaite et al., 2005; Vargas-Franco et al., 2010). (5) The T3 terrace would only be flooded by voluminous lahars linked to a sizeable volcanic eruption ( $>$ VEI3, i.e. volume of deposits $\geq 1 \mathrm{~km}^{3}$ ). The volume of syn- or post-eruption lahars could exceed 4 million $\mathrm{m}^{3}$. The most recent sizeable volcanic eruption ( $>$ VEI3) at El Misti occurred about $2030 \mathrm{yr}$ ago (Thouret et al., 2001; Harper et al., 2011; Cobeñas et al., 2012).

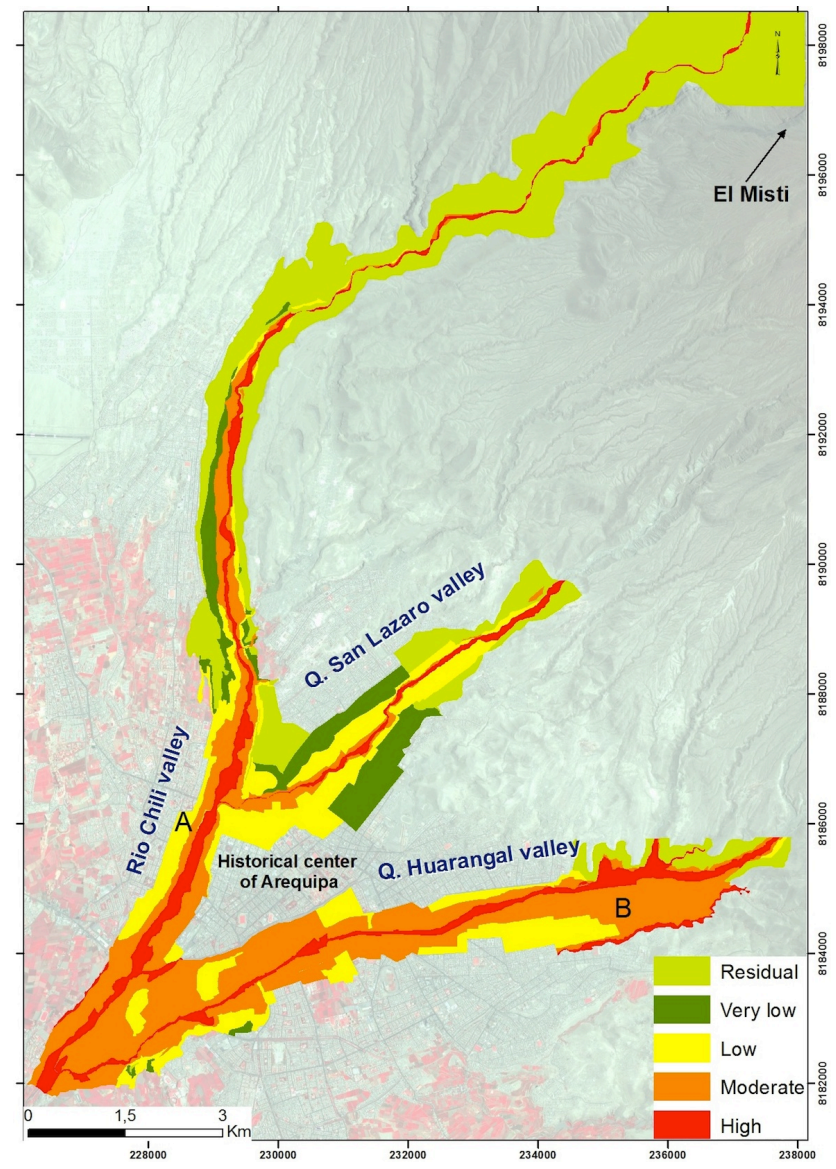

Fig. 5. Lahar-prone areas in the city of Arequipa. Hazard level (HL) includes five classes according to Table 3. Letters A and B refer to the places where pictures in Fig. 3 were taken.

Figure 5 shows the areas that potentially could be affected by lahars and flash floods in the city of Arequipa, along the Río Chili valley, Qda. Huarangal (NE) and Qda. San Lazaro north of the city. Mapping flash floods and lahar hazard zones is different from other volcanic-hazard zoning as lahars and floods are usually confined to valleys, i.e. along the Río Chili valley across the city and the two main quebradas. However, Fig. 6 shows that overbank flooding can occur along the gently sloping Río Chili valley, in particular on the left bank (T1 and T1') near the city centre, e.g. in 1989, and upstream of the confluence with Río Andamayo, e.g. as in 2011. As a result, for some city blocks (e.g. in 1989), crops and recreation areas (e.g. as in 2011) can be damaged.

\subsection{Hazard and land use}

When a lahar occurs, the material density and flow speed are critical characteristics, which generate a dynamic over-pressure on buildings, bridges and/or lifelines in the city (Zanchetta et al., 2004). As a result, the observed damage results from the dynamic pressure generated by the flow. 
Table 3. Measuring hazard parameters at the city-block scale. Hazard levels resulting from the delineation of terraces (height above channel and return period) are represented in Fig. 5.

\begin{tabular}{|c|c|c|c|c|c|c|}
\hline \multirow[t]{2}{*}{ Hazard level } & \multirow[t]{2}{*}{ GIS grade } & \multirow{2}{*}{$\begin{array}{l}\text { Terraces } \\
\text { Number }\end{array}$} & \multicolumn{2}{|l|}{ Flash floods } & \multicolumn{2}{|c|}{$\begin{array}{l}\text { Lahars } \\
\text { (hyperconcentrated streamflows } \\
\text { and debris flows) }\end{array}$} \\
\hline & & & Return period & Discharge $\left(\mathrm{m}^{3} \mathrm{~s}\right)^{-1}$ & Return period & Discharge $\left(\mathrm{m}^{3} \mathrm{~s}\right)^{-1}$ \\
\hline High & 5 & $\mathrm{~T} 0+\mathrm{T} 1$ & $10-100$ & $5-10$ & $>0.5$ & $10-50$ \\
\hline Moderate & 4 & $\mathrm{~T} 1{ }^{\prime}+\mathrm{T} 2$ & $100-150$ & $>10-50$ & $0.5-1.5$ & $50-100$ \\
\hline Low & 3 & $\mathrm{~T} 2^{\prime}+\mathrm{T} 3$ & $150-260$ & $50-100$ & $1.5-4$ & $>100-1000$ \\
\hline Very low & 2 & $\mathrm{~T} 4$ & $>260$ & $>100-1000$ & $4-11$ & $>1000-10000$ \\
\hline Residual & 1 & Above T4 & - & - & - & - \\
\hline
\end{tabular}

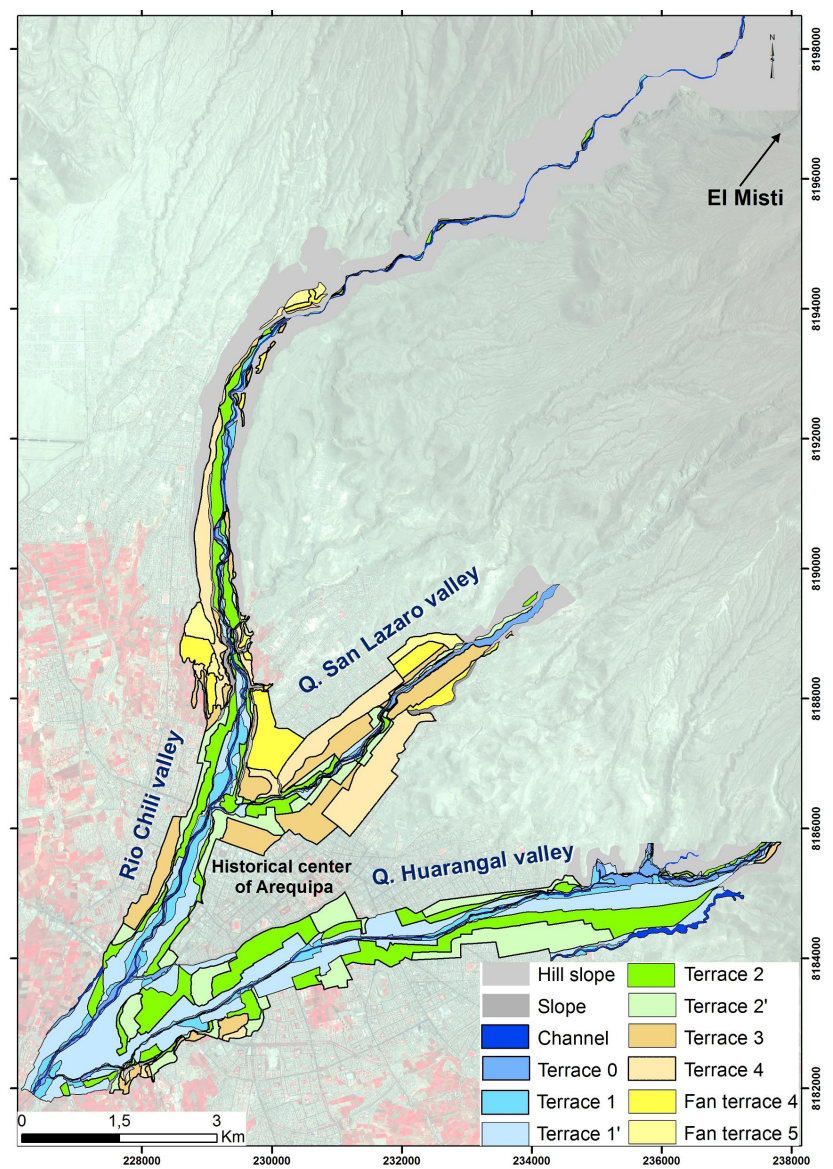

Fig. 6. Terraces in the city centre of Arequipa. This figure shows the system of terraces in the centre of Arequipa, from river channels to fan terraces. The delineated terraces are completed with land use types identified on each of the banks of Río Chili (see Fig. 7).

Dynamic pressure depends on flow velocity, flow density and on the resistance of the building or urban infrastructure (material, cement, structure, etc.). The resistance of housing and infrastructure (bridges, roads, lifelines, etc.) is variable according to the nature of the flows; i.e. the velocity of a hyperconcentrated streamflow is rapid but its density will remain lower than that of a debris flow. However, the effect of the lahars and floods also depends on the location of housing and bridges with respect to the channel bed and lahar flow. For instance, an embankment may change the height and speed of the flow. The 1989 decadal flood of Río Chili (discharge on the order of $200 \mathrm{~m}^{3} \mathrm{~s}^{-1}$ ) shows that the terrace T1', located 3 to $4 \mathrm{~m}$ above the river bed on the left bank near the city centre, can be extensively flooded. Flooding on the left bank can be favoured by the recent bridge below the colonial "Grau", which is vulnerable owing to its low strength and table only $4 \mathrm{~m}$ above the river bed.

Figure 7 indicates that the historical centre of Arequipa is bounded by the banks of the Río Chili and quebradas San Lazaro and Huarangal. The banks of the valleys host perennial activities. For instance, the main power plant of the city is located on the terrace T1'-T2 of the Río Chili, $3 \mathrm{~km}$ upstream from the city centre. Residential and recreational activities take place on most of the lowest terraces (T0 and $\mathrm{T} 1$ ) and a large part of the highest ones (T1' to T4). Most industrial and commercial activities are located downstream from the city on intermediate terraces (T1' to T3). Such location and exposure of land-use types and businesses near the riverbeds are therefore a source of vulnerability in case of flooding.

\section{Evaluating vulnerability and exposure to lahars and floods in Arequipa}

This section considers the vulnerability of the city based on both physical and socio-economic components. The magnitude of risk is added to these usual components by measuring how much a given city block can become isolated from vital resources in the case of a crisis. Relevant data used in our evaluation derive from the official land-use planning of Arequipa (Municipalidad Provincial de Arequipa, 2002), booklets from risk-management institutions belonging to the Civil 

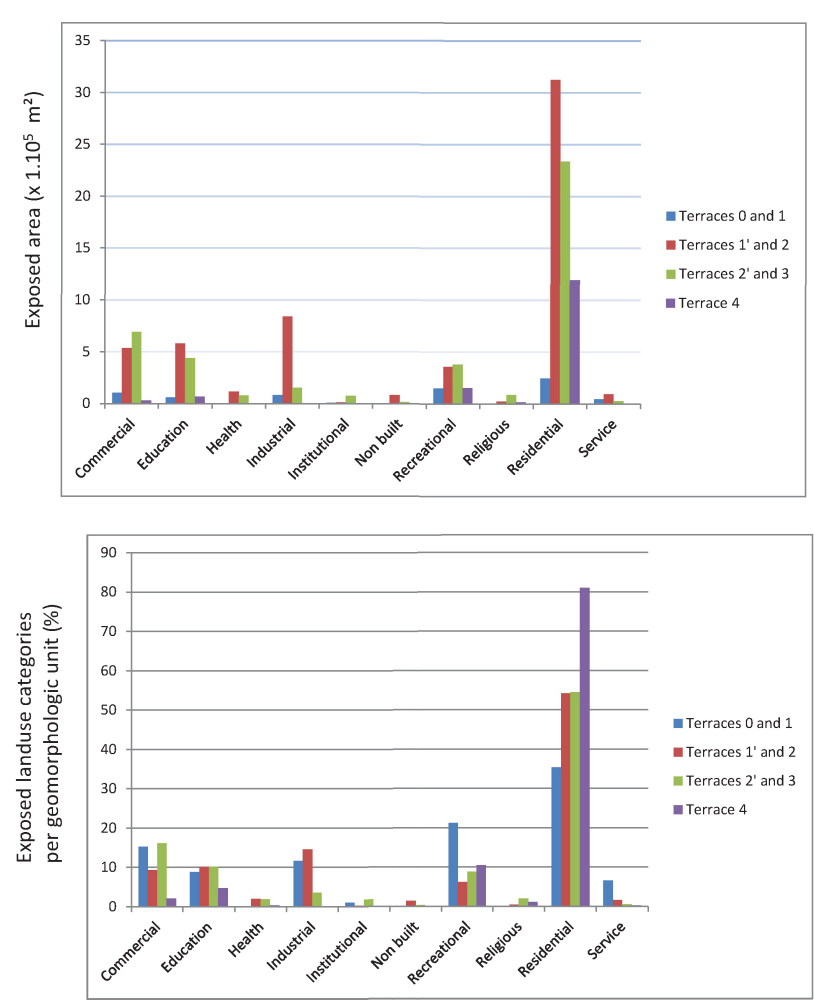

Fig. 7. Exposure of at-risk land-use types along the Río Chili valley, according to the height of the terrace above the channel (after Vargas-Franco et al., 2010, modified). The delineation of terraces is based on the hazard-zone map shown in Fig. 6. The census of activities is based on field surveys and aerial surveys using Google Earth Pro $^{\mathrm{TM}}$.

Protection agencies, and aerial surveys using Google Earth Pro $^{\mathrm{TM}}$.

\subsection{Physical vulnerability}

The evaluation of physical vulnerability is based on the characteristics of buildings. Three principal criteria are taken into account: (1) the size of the buildings, a high building being less vulnerable to floods; (2) the quality of construction; and (3) the population density. Although population density strictly speaking is not a building characteristic, such data help to make physical vulnerability also reflect overall vulnerability. Two types of indexes are computed: (1) a building vulnerability index $(\mathrm{BuV})$, which is obtained by the combination of the characteristics mentioned above, and (2) a residential vulnerability index (RvI) resulting in a discrete scale of residential vulnerability index (RvI). The details of the computations is given in Table 4.

The five classes of residential vulnerability index are represented in Fig. 8 for the entire city of Arequipa. This map extends previous works performed in pilot areas (Martelli et al., 2010). Thanks to the surveys made by the Civil Protec-

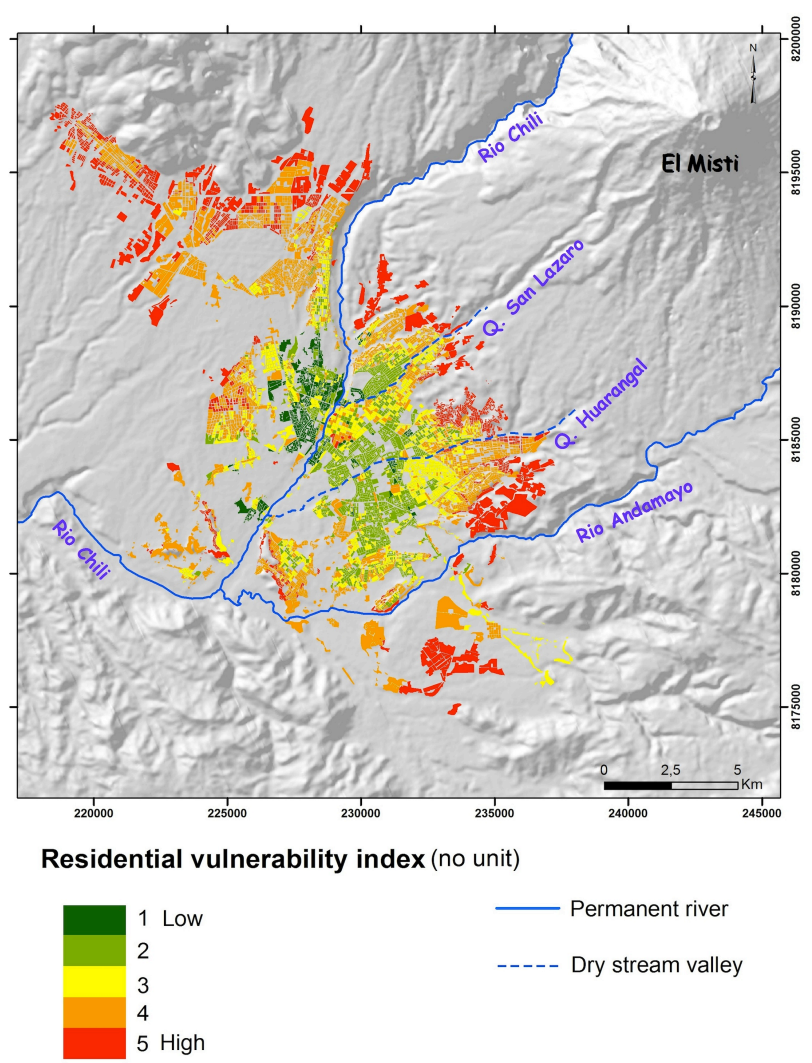

Fig. 8. Map of the residential vulnerability in Arequipa. The residential vulnerability index (RvI) comprises five classes (see Table 4). The scale of original data (city block) ensures a high level of precision. Using this general map, one can focus on specific areas without any additional computation.

tion offices, the precision of this analysis now pertains to the block scale. The results shown in Fig. 8 exhibit roughly concentric zones around Yanahuara district (west bank of Río Chili), where buildings are newer and made of more-resistant materials, and the city centre (east bank), which is composed of mostly historic buildings of weaker construction. Starting from the centre, vulnerability increases outward and attains its highest level in the outskirts of the city. These suburbs usually host "unofficial" housing sites for newcomers from rural areas. The migrant populations have chosen such neighbourhoods by default, simply because they constitute the only available affordable space to build a house, usually made of the least-expensive, weak materials. In addition, these poorly-built suburbs are among the most densely populated in the city (e.g. 10432 inhabitants per km² in Alto Selva Alegre and 9100 in Yanahuara in 2007).

\subsection{Socio-economic vulnerability}

The physical vulnerability of housing has been then combined with socio-economic criteria to give an indication of both physical and social vulnerability. Because of the lack 


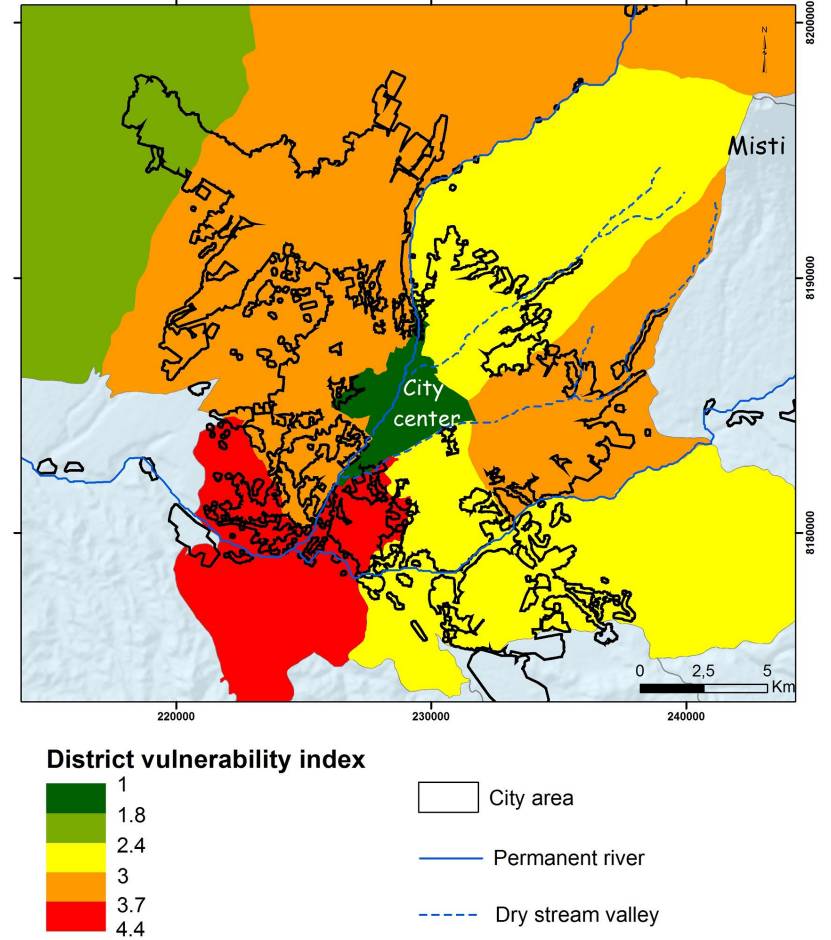

Fig. 9. Map of the socio-economic vulnerability in Arequipa. Socioeconomic vulnerability index (SEvI) comprises five classes (see Table 5). Due to the scale of original data (city district), this map is less precise than the others maps obtained from this research.

of data at the scale of city blocks, the criteria are defined at the scale of city districts. A socio-vulnerability (SEvI) index has been computed which combines unemployment rates, the quality of public services and the lack of schools with an equal weight (Table 5). The final vulnerability index (SEvI) is made up of five classes for which each criterion has been weighted on an equal basis.

Figure 9 shows the distribution of the socio-economic vulnerability index for the entire city. Because of data limitations, the map is depicted at the district scale, while all other maps considered in this analysis are drawn at the city-block scale. Despite this poorer precision, much can be learned about the extent and location of poverty in the city. Socioeconomic vulnerability is quite low in the city centre due to commercial and touristic activities, which generate sustained economic activity. Outside the city centre livelihood conditions are more precarious. Despite the relatively crude scale of the map, a correlation between the quality of buildings (Fig. 8) and the living standard of the population can be observed. The distance to the city centre appears proportional to the density and inversely proportional to people's vulnerability. Populations living along the quebradas generally have a lower level of income and education than those in other districts (Municipalidad Provincial de Arequipa, 2002). The districts and suburbs of the city located on the upper part and the most recently built fans (e.g. Alto Selva Alegre, Alto Misti and Alto Grau), and on the lower flanks of El Misti (e.g. Alto Belen upstream of Mariano Melgar) are the poorest areas.

\subsection{Evaluating exposure: the "isolation" factor}

To overcome the inadequacy of available socio-economic data, "isolation" of districts and blocks has been analysed. "Isolation" is a measure of exposure which reflects the unequal exposure of the population towards risk and its unequal access to vital resources such as "safe" areas, hospitals or drinking water (Cannon, 1993). This issue becomes crucial during a crisis and disaster, as people need to be evacuated or rescued in a short amount of time. As a result, people located in very hazardous areas but close to resources may be less affected by damaging lahars and floods without resulting in high harm or death. Conversely, people, even if relatively safe from hazards, may suffer from their indirect impact if they lack or lose access to potable water (McEntire, 2001).

In the case of an emergency, the distance between the population and exposed resource elements and "safe" areas plays a major role in saving lives (Tatham and Kovacs, 2007). Therefore, isolation is measured in terms of distance from vital resources. Table 6a summarizes the indicators used to compute a "global" isolation index (II) based on (i) distance to hospitals (Fig. 10a) and fire stations (Fig. 10b), which represents immediate needs; (ii) distance to "safe", large and open areas (Fig. 10c), either stadiums or car parks, that can be used for shelters; and (iii) distance to water tanks (Fig. 10d), if access to running water is disrupted. The "distance" maps reveal major inequalities in ease of rescue in the case of a crisis. For instance, most medical centres are located in the city centre (Fig. 10a). The populations located in the suburbs of the city, especially in the upper reaches of the quebradas, cannot easily access hospitals or even dispensaries. Combined with a lack of nearby fire stations (Fig. 10b), this situation makes it necessary to identify safe areas where mobile rescue units can be deployed in case of floods and lahars.

In contrast with the entire city of Arequipa, which is directly and widely exposed to volcanic hazards, many districts are protected from flash floods outside the quebradas and El Misti slopes (Fig. 5). In these districts the identification of potential "safe areas" allows a response unit to be provided to the population in the flood-prone districts. Figure 10c indicates all safe areas that have been identified in the city of Arequipa. The map shows a rather uniform distribution, although many districts located outside the city centre (mainly north and south) lack safe areas. These areas should be located outside of the quebradas but close to them in order to host small command units and temporary shelters as well as to facilitate the distribution of emergency relief. They should be easily converted in the case of emergency to provide basic needs to the population. For instance, parks, playgrounds and sport fields are free from buildings and can easily serve as 
A. Distance to hospitals

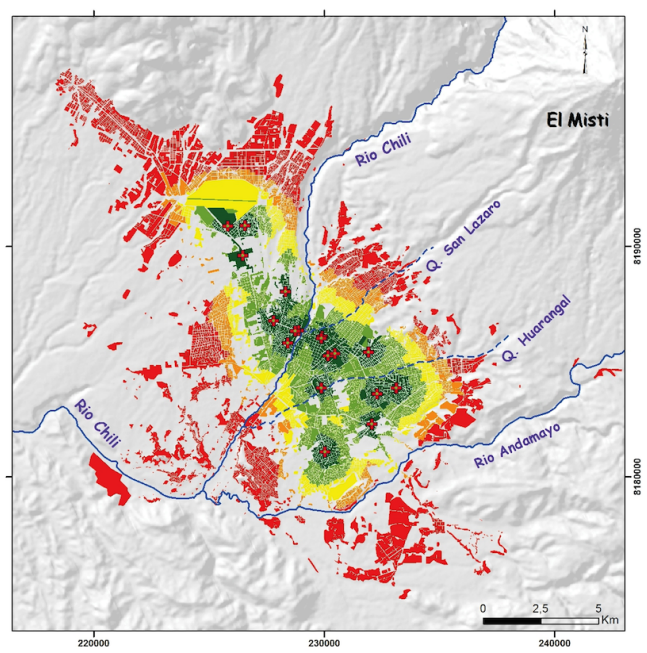

C. Distance to 'safe' areas

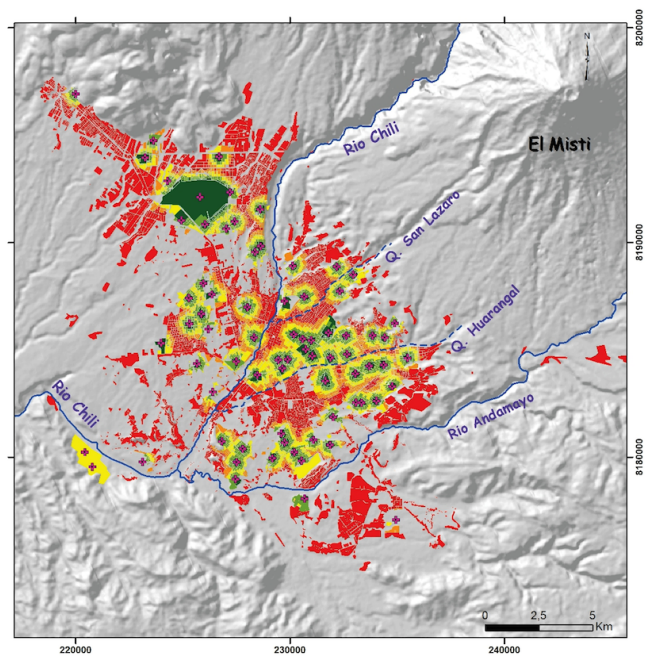

B. Distance to fire stations

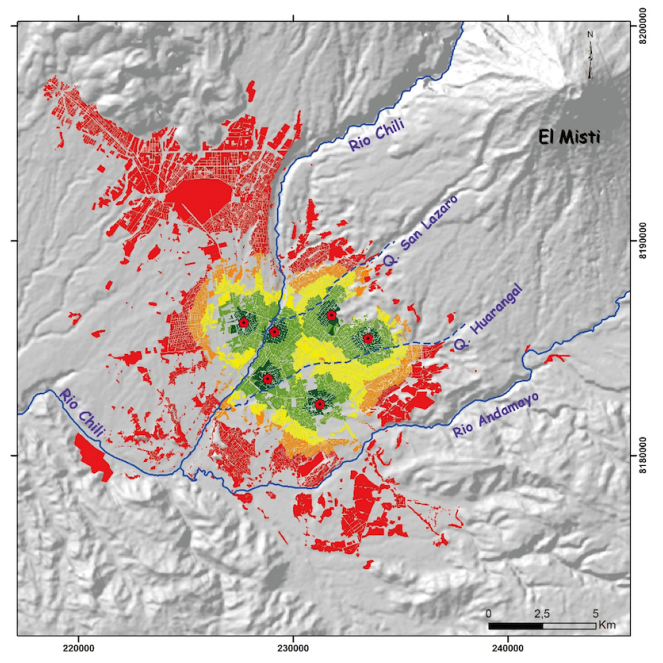

D. Distance to water tanks

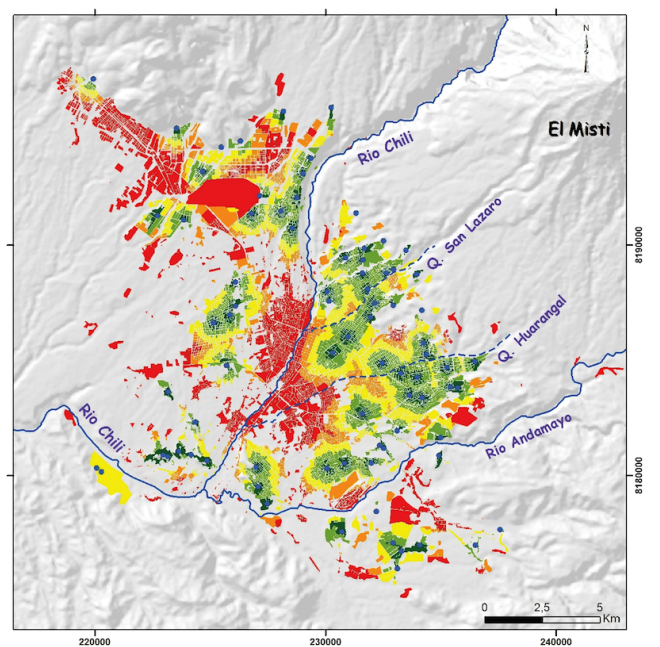

\begin{tabular}{|l|l|l|l|}
\hline Distance to : weighted by the quality of cross roads \\
\hline Safe areas (10A) & Fire stations (10B) & Water tanks (10C) & Hospitals (10D) \\
\hline O to $250 \mathrm{~m}$ & 0 to $1000 \mathrm{~m}$ & 0 to $500 \mathrm{~m}$ & 0 to $1000 \mathrm{~m}$ \\
\hline 251 to $500 \mathrm{~m}$ & 1001 to $2000 \mathrm{~m}$ & 501 to $1000 \mathrm{~m}$ & 1001 to $2000 \mathrm{~m}$ \\
\hline 501 to $750 \mathrm{~m}$ & 2001 to $3000 \mathrm{~m}$ & 1001 to $1500 \mathrm{~m}$ & 2001 to $3000 \mathrm{~m}$ \\
\hline 751 to $1000 \mathrm{~m}$ & 3001 to $4000 \mathrm{~m}$ & 1501 to $2000 \mathrm{~m}$ & 3001 to $4000 \mathrm{~m}$ \\
\hline More than $1001 \mathrm{~m}$ & More than $4001 \mathrm{~m}$ & More than $2001 \mathrm{~m}$ & More than $4001 \mathrm{~m}$ \\
\hline
\end{tabular}

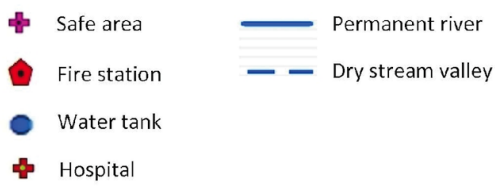

Fig. 10. Distances to hospitals, "safe" areas and water tanks in Arequipa. The figures represent the measure of isolation at the block scale including hospitals (A), fire stations (B), and "safe" areas such as parks and playgrounds (C) and water tanks (D). The resources (hospitals, etc.) were identified using field and aerial surveys. The distance includes five classes for each indicator (see Table 6a). The distance also takes into account the road conditions (Table 6b).

emergency-shelter areas. Also, large sporting facilities such as football stadiums and sports clubs (e.g. Arequipa's Melgar team stadium) as well as the airport area meet these criteria. However, safe areas can only be used if they remain accessible by road from other parts of the city.
People can also become isolated if they lack resources such as water during a crisis. As much as $90 \%$ of the city of Arequipa is connected to running water, which is supplied by the Río Chili catchment. Facing the risk of a water shortage, the company termed SEDAPAR in charge of water supply decided in 2010 to launch an audit. The aim was to 
Table 4. Evaluating building vulnerability. Building vulnerability $(\mathrm{BuV})$ is defined as a multiplicative function of the size, the quality of construction of buildings and the population density. Data stems from the official urban-planning scheme of Arequipa (Municipalidad Provincial de Arequipa, 2002). The data precision is at the city-block scale. To obtain a discrete indicator, five classes of residential vulnerability (RvI) were created. Classes take into account how skewed distributions can be generated by multiplication. The map of building vulnerability for the whole city of Arequipa is shown in Fig. 8.

\begin{tabular}{|c|c|c|c|c|}
\hline Name & Data used & Sources & Calculation & $\begin{array}{l}\text { Scale of } \\
\text { observation }\end{array}$ \\
\hline $\begin{array}{l}\text { Building } \\
\text { size }\end{array}$ & $\begin{array}{l}\text { Number of } \\
\text { storeys }\end{array}$ & $\begin{array}{l}\text { Municipalidad } \\
\text { Provincial de } \\
\text { Arequipa (2002) }\end{array}$ & $\begin{array}{l}\text { Ranked from } 1 \text { to } 4: \\
4 \text { storeys and more }=1 \\
3 \text { storeys }=2 \\
2 \text { storeys }=3 \\
1 \text { storey }=4\end{array}$ & City block \\
\hline $\begin{array}{l}\text { Building } \\
\text { conservation }\end{array}$ & $\begin{array}{l}\text { Expert } \\
\text { knowledge }\end{array}$ & $\begin{array}{l}\text { Municipalidad Provincial } \\
\text { de Arequipa (2002) }\end{array}$ & $\begin{array}{l}\text { Ranked from } 1 \text { to } 3: \\
\text { Good maintenance }=1 \\
\text { Medium maintenance }=2 \\
\text { Bad maintenance }=3\end{array}$ & City block \\
\hline $\begin{array}{l}\text { Population } \\
\text { density }\end{array}$ & Census & $\begin{array}{l}\text { Municipalidad Provincial } \\
\text { de Arequipa (2002) }\end{array}$ & $\begin{array}{l}\text { Ranked from } 1 \text { to } 4: \\
\text { High }=1 \\
\text { Medium }=2 \\
\text { Low }=3 \\
\text { Very low }=4\end{array}$ & City block \\
\hline $\begin{array}{l}\text { Building } \\
\text { vulnerability } \\
\text { index }(\mathrm{BuV})\end{array}$ & & & $\begin{array}{l}\text { BuV: Building size X Building } \\
\text { quality of construction X Popu- } \\
\text { lation density }\end{array}$ & City block \\
\hline $\begin{array}{l}\text { Residential } \\
\text { vulnerability } \\
\text { index (RvI) }\end{array}$ & & & $\begin{array}{l}\text { Index from } 1 \text { to } 5: \\
R v I=1 \text { if } \mathrm{BuV}=1 \text { to } 3 \\
\mathrm{RvI}=2 \text { if } \mathrm{BuV}=4 \text { to } 6 \\
\mathrm{RvI}=3 \text { if } \mathrm{BuV}=7 \text { to } 12 \\
\mathrm{RvI}=4 \text { if } \mathrm{BuV}=13 \text { to } 24 \\
\mathrm{RvI}=5 \text { if } \mathrm{BuV}=25 \text { to } 48\end{array}$ & City block \\
\hline
\end{tabular}

Table 5. Evaluating the socio-economic vulnerability. The measure of socio-economic vulnerability is carried out at the district scale, which is the lowest administrative division in Arequipa. However, this scale offers much less precision than that for the city-block scale. Original data (unemployment, access to public services, and inadequate number of schools) is fitted to build a global vulnerability index (SEvI) scaled from 1 to 5. The map of socio-economic vulnerability for the whole city of Arequipa is shown in Fig. 9.

\begin{tabular}{lllll}
\hline Name & Data used & Sources & Calculation & $\begin{array}{l}\text { Scale of } \\
\text { observation }\end{array}$ \\
\hline $\begin{array}{l}\text { Unemployment } \\
(\% \mathrm{U})\end{array}$ & Census & $\begin{array}{l}\text { Municipalidad Provincial } \\
\text { de Arequipa (2002) }\end{array}$ & $\begin{array}{l}\text { Original data between } 8.1 \% \text { and } 13.3 \% \\
\text { Fitted index: Iu }=0.77 *(\% \mathrm{U})-5.23\end{array}$ & District \\
\hline $\begin{array}{l}\text { Service sector } \\
(\% \mathrm{Ss})\end{array}$ & Census & $\begin{array}{l}\text { Municipalidad Provincial } \\
\text { de Arequipa (2002) }\end{array}$ & $\begin{array}{l}\text { Original data between } 30.4 \% \text { and } 81.3 \% \\
\text { Fitted index: Iss }=-0.0786 *(\% \mathrm{Ss})+7.39\end{array}$ & District \\
\hline $\begin{array}{l}\text { Inadequate number of } \\
\text { schools }(\% \mathrm{Ns})\end{array}$ & Census & $\begin{array}{l}\text { Municipalidad Provincial } \\
\text { de Arequipa (2002) }\end{array}$ & $\begin{array}{l}\text { Original data between } 0 \% \text { and } 56.73 \% \\
\text { Fitted index: Ins }=0.07 *(\% \mathrm{Ns})+1\end{array}$ & District \\
\hline $\begin{array}{l}\text { District vulnerability } \\
\text { index (SEvI) }\end{array}$ & & & $\begin{array}{l}\text { From 1 (low vulnerability) to 5 (high vulnerability) } \\
\text { SEvI }=(\text { Iu + Iss }+ \text { Ins) } / 3\end{array}$ & District \\
\hline
\end{tabular}

identify all the wells and water tanks across the city and to evaluate their capacity for the basic needs of the population. The results have yielded a strategic document at city scale, which showed that each district could receive enough water for many days in case of a disruption of water supply from the principal Río Chili catchment. Yet the location of water tanks in case of disruption shows a heterogeneous distribution of this facility throughout the city (Fig. 10d). Blocks located near the boundaries of the city, in particular on the sloping piedmonts that ring El Misti, benefit by being close 
Table 6a. Evaluating the "isolation" factor (see text for discussion). The measurement of "isolation" has been carried out at the city-block scale. All variables are divided into five classes and mapped (Fig. 10). For the computation of overall isolation (Table 6a), a weighting factor equal to 1 is assigned to critical facilities such as hospitals, fire stations and safety areas, while a weighting factor equal to 0.5 is assigned to non-essential facilities such as water tanks. The map of "isolation" for the whole city of Arequipa is shown in Fig. 11. Starting from the computation of the isolation index (II), the mapping takes into account road conditions and natural constraints (rivers and bridges). Poor road conditions result in additional travel time to facilities and an increase in isolation (Table 6b).

\begin{tabular}{|c|c|c|c|c|}
\hline $\begin{array}{l}\text { Computation of isolation } \\
\text { Name }\end{array}$ & Data used & Sources & Calculation & $\begin{array}{l}\text { Scale of } \\
\text { observation }\end{array}$ \\
\hline $\begin{array}{l}\text { Distance to hospitals } \\
\text { (DH) }\end{array}$ & $\begin{array}{l}\text { Public and large private } \\
\text { hospitals }\end{array}$ & $\begin{array}{l}\text { Google Maps }^{\mathrm{TM}} \text { (2011), } \\
\text { Gobierno Regional } \\
\text { de Arequipa (2007), } \\
\text { Municipalidad Provincial } \\
\text { de Arequipa (2002) }\end{array}$ & $\begin{array}{l}\text { From } 1 \text { to 5: A class each } 1000 \mathrm{~m} \text {. } \\
\text { Elaborated with ArcGIS's Spatial } \\
\text { Analyst using a road cost raster }\end{array}$ & City block \\
\hline $\begin{array}{l}\text { Distance to fire stations } \\
\text { (DFS) }\end{array}$ & Fire stations & $\begin{array}{l}\text { Cuerpo General de Bomberos } \\
\text { Voluntarios del Perú (2012) }\end{array}$ & $\begin{array}{l}\text { From } 1 \text { to 5: A class each } 1000 \mathrm{~m} \text {. } \\
\text { Elaborated with ArcGIS's Spatial } \\
\text { Analyst using a road cost raster }\end{array}$ & City block \\
\hline $\begin{array}{l}\text { Distance to safety areas } \\
\text { (DSA) }\end{array}$ & $\begin{array}{l}\text { Stadiums and car parks, } \\
\text { surface }>3500 \mathrm{~m}^{2}\end{array}$ & Google Earth Pro ${ }^{\mathrm{TM}}$ (2011) & $\begin{array}{l}\text { From } 1 \text { to 5: A class each } 250 \mathrm{~m} \text {. } \\
\text { Elaborated with ArcGIS's Spatial } \\
\text { Analyst using a road cost raster }\end{array}$ & City block \\
\hline $\begin{array}{l}\text { Distance to water tanks } \\
\text { (DWT) }\end{array}$ & Water tanks & Google Earth Pro ${ }^{\mathrm{TM}}$ (2011) & $\begin{array}{l}\text { From } 1 \text { to } 5 \text { : A class each } 500 \mathrm{~m} \text {. } \\
\text { Elaborated with ArcGIS's Spatial } \\
\text { Analyst using a road cost raster }\end{array}$ & City block \\
\hline $\begin{array}{l}\text { Isolation index } \\
\text { (II) }\end{array}$ & & & $\begin{array}{l}\text { From } 1 \text { (low isolation }=\text { short distance) } \\
\text { to } 5 \text { (high isolation = long distance). } \\
\text { Multiple criteria analysis: } \\
\text { - Vital facility: weighting factor } 1 \\
\text { - Other facility: weighting factor } 0.5 \\
\text { Formula: II } \\
=(\mathrm{DH}+\mathrm{DFS}+\mathrm{DSA}+1 / 2 \mathrm{xDWT}) / 3.5\end{array}$ & City block \\
\hline
\end{tabular}

Table 6b. Road conditions. Starting from the computation of the isolation index (II), the mapping takes into account road conditions and natural constraints (rivers and bridges). Poor road conditions result in additional travel time to facilities and an increase in isolation.

\begin{tabular}{lll}
\hline \multicolumn{2}{l}{ Road conditions } & Weigh coefficient \\
Road type & Criteria & $1 \mathrm{~m}=1$ \\
\hline Type 1 & Major roads. & $1 \mathrm{~m}=1.5$ \\
Type 2 & Good, large and paved streets. & $1 \mathrm{~m}=1.7$ \\
Type 3 & Half paved and half dirt (or gravel road). Well graded and maintained. & $1 \mathrm{~m}=1.9$ \\
Type 4 & Gravel road or dirt road, sometimes with slope. Badly or even not graded. & $1 \mathrm{~m}=2.1$ \\
Type 5 & Out of the city, connection with remote houses. & $1 \mathrm{~m}=3$ \\
Bridges & & Cannot be crossed without bridges \\
Rivers & & \\
\hline
\end{tabular}

to the reservoirs, even though they do not have any access to running water. In contrast, the city centre, which has running water, appears to be more vulnerable to a water shortage, should the Río Chili water system be disrupted.

The four categories of indicators (distance to hospitals, fire stations, safe areas and water tanks) that have been taken into account exhibit a contrasted isolation for each city block. The details of the computing of the overall isolation index (II) is presented in Table 6. The evaluation of the isolation index takes into account road conditions, as distances can be measured in kilometres and time (D'Ercole and Metzger, 2004). While major roads are paved and remain usable during heavy rainfall, dirt roads may delay or even hinder evacuations. The key role of bridges was accounted for as they can be closed, damaged or destroyed by a lahar. Isolation at city scale is given by Fig. 11 and reveals an obvious gap between the centre and the periphery. In general, the city centre benefits from good access to vital resources (health centres and evacuation areas), even though Río Chili and Qda. San Lazaro and Qda. Huarangal crisscross it. The density of bridges and the quality of road pavement allows people to overcome this natural constraint, but the inner part of Arequipa is vulnerable to water disruption. In contrast, all blocks located in suburbs in the 
Table 7. Evaluating the overall vulnerability. This table provides the calculation of the population vulnerability index (PVI), which combines residential vulnerability, socio-economic vulnerability and the isolation index. The overall measure is provided at the city-block scale, although the socio-economic vulnerability is computed at the district scale. Figure 12 shows a map representing PVI.

\begin{tabular}{lll}
\hline Name & Calculation & Scale of observation \\
\hline Population vulnerability index (PvI) & PvI $=(\mathrm{II}+\mathrm{RvI}+\mathrm{SEvI} / 10) / 2,1$ & City block \\
& or PvI $=(\mathrm{II}+\mathrm{SEvI} / 10) / 1,1$ for & \\
& $\begin{array}{l}\text { city blocks with no residential } \\
\text { buildings }\end{array}$ & \\
& & \\
\hline
\end{tabular}

Table 8. Evaluating the risk level based on hazard level and overall population vulnerability. This table provides an overall measure of flood and lahar risk for the city of Arequipa. The lahar risk level (LRL) is the combination (using an equal weight) of the hazard level calculated in Table 3 and the population vulnerability index calculated in Table 7. Starting from its elaboration, LRL only concerns the banks of the rivers and the quebradas that cross Arequipa. Figure 13 shows the resulting map for the whole city and Fig. 14 for Quebrada San Lazaro.

\begin{tabular}{lll}
\hline Name & Calculation & Scale of observation \\
\hline Hazard level (HL) & From 1 to 5 (Table 3) & City block \\
\hline Population vulnerability index (PvI) & From 1 to 5 (Table 7) & City block \\
\hline Lahar risk level (LRL) & If PvI $=0, \mathrm{LRL}=0$ & City block \\
& If PvI $>0$ and HL $\leq 1, \mathrm{LRL}=1$ & \\
& If PvI $>0 \quad$ and $\quad \mathrm{HL}>1$, & \\
& $\mathrm{LRL}=(\mathrm{PvI}+\mathrm{HL}) / 2$ \\
\hline
\end{tabular}

periphery are quite landlocked with poor access to vital facilities such as hospitals, with the exception of water supply.

\subsection{Overall vulnerability}

By combining data from building vulnerability, socioeconomic vulnerability and exposure to hazards, an overall vulnerability index (PvI) has been created. Indicators of physical vulnerability and isolation are included in the formulae with an equal weight, while socio-economic parameters are underweighted for scale reasons (Table 7). A scale of overall population vulnerability from 0 to 5 (PvI: Fig. 12) has been computed. The overall vulnerability map reinforces the results obtained by using the isolation index (Fig. 11), and in particular the contrasting situation between the city centre and the suburbs is emphasized. Vulnerability increases with distance from the city centre. Areas located in recent and remote suburbs near the boundaries of the city, on the upper banks of the quebradas and in the northern part of the city are the most vulnerable. Poor quality of housing, lack of education, high unemployment rates and isolation from vital resources characterize these neighbourhoods.

\section{Defining and outlining risk areas}

Finally, the lahar and flood risk maps (Figs. 13 and 14) have been prepared at the city scale, in order to encompass the Río Chili valley and all quebradas across the districts that are threatened by lahars and flash floods. These maps show the degree of risk that each city block of the city faces from lahars and flash floods. They also outline areas at risk in case of heavy rainfall.

\subsection{Definition and results}

The method for computing risk is described in Table 8 . The lahar risk level (LRL) has been defined as the combination (using an equal weight) of the hazard level calculated in Table 3 and the population vulnerability index calculated in Table 7. As with the case for hazards and vulnerability, the risk scale is defined from 0 to 5 . This measure of the risk level using an averaging of both hazard and vulnerability attributes the same weight to hazard and vulnerability in the computation of the risk level. The lahar risk level also presents the advantage of making a non-zero risk appear as soon as the land is populated. Such residual risk takes into account the possibility of water runoff in the streets, even outside of the quebradas in the case of heavy rainfall (e.g. in 2011).

Figure 13 presents the resulting lahar- and flood-risk map at the city scale and for each block. Areas at risk are obviously located along the main valleys that cut the city, with the city centre contrasting with the suburbs. Many poor districts located in relatively isolated areas on the lower volcano flanks are safe from lahars (but not from heavy runoff), whereas wealthier districts located near the city centre and close to the valley channels on low terraces are at risk. The principal areas at risk are located along Qda. San Huarangal, 


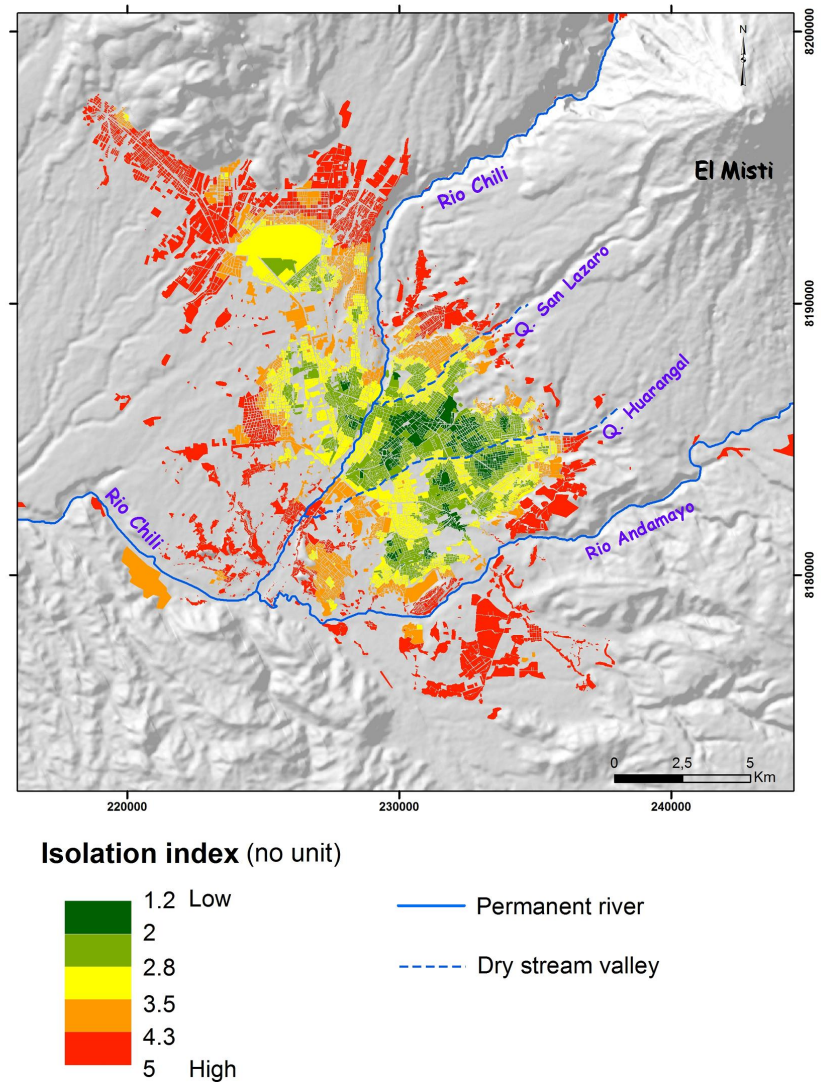

Fig. 11. Map showing the combined "isolation" of the population in Arequipa. The overall isolation index (II) comprises five classes (see Table 6a). The map takes into account road conditions (Table $6 \mathrm{~b}$ ). The scale of original data (city block) results in a high level of precision.

both in its upper reaches and at its confluence with Río Chili. The high-risk areas mostly correspond to new and precarious "illegal" settlements, situated upstream on the formerly nonbuilt areas on the volcano slopes and down valley in former agricultural areas. Along the entire Quebrada reaches and on both banks, an area $1 \mathrm{~km}$ across is moderately exposed to lahar risk. Some residential areas located in Río Chili, such as Obrero (terrace T1', downstream from the Grau bridge) are also among the most dangerous areas. A lot of strategic infrastructure located in the Río Chili valley is also in areas at risk: (1) the main water intake located in the upper Río Chili valley (Fig. 1) and (2) the principal power plant of the city on terrace T1'-T2 located on the left bank of the river. The water intake may be damaged or destroyed in the case of a 5- to 10 -yr return event, while the power plant may be damaged in case of a 50-yr return event. Quebrada San Lazaro is also at risk from lahars and flash floods (Fig. 14), with the exposed area reaching $1 \mathrm{~km}$ between banks; this is less extensive than the wide fan of Quebrada Huarangal. However, the 5- to 10m-deep channel means that the risk is much lower: the entire valley (located on terrace T3) may be severely damaged in

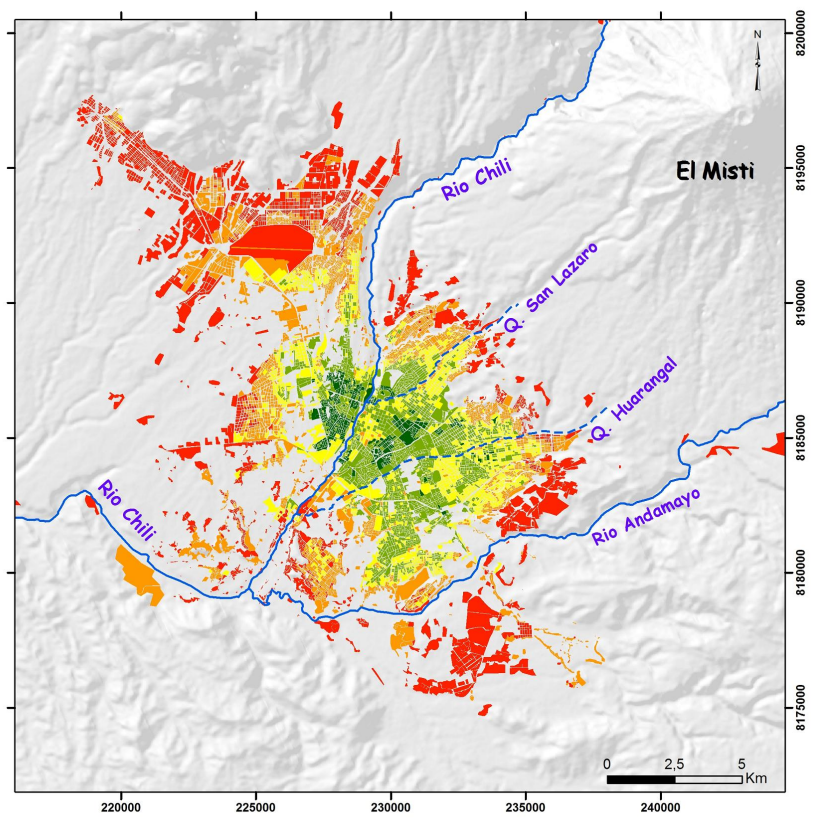

Population vulnerability index (no unit)
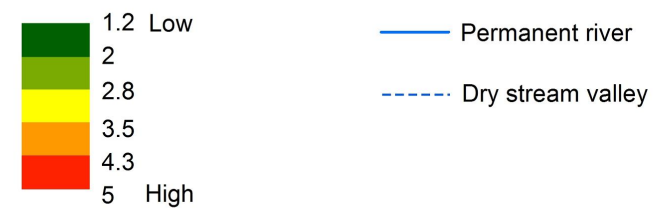

Fig. 12. Map of the overall population vulnerability in Arequipa. The overall vulnerability index comprises ofive classes according to Table 7 (PvI). The scale of original data (city block) results in a high level of precision.

the case of rare but intense events (return period $>150 \mathrm{yr}$ ) rather than smaller events. The population living near the Qda. San Lazaro is vulnerable because fire stations and hospitals are far away. In addition, a small number of safe areas only can be converted into shelters or evacuation centres across this area, which could pose a complex logistical problem in case of crisis.

Figures 13 and 14 allow us to better visualize where the areas at risk from lahar impacts are located in the city of Arequipa. However, the maps have the drawback of not linking lahars with their origin (e.g. intense rainfalls), whose consequences are also critical. For instance, heavy rainfall may cause damage to roads, which may disable rescue units. Between 10 and 16 February 2011, rescue units could not access all districts because many roads were destroyed. Therefore, Figs. 13 and 14 must not belie the fact that all districts located outside the valleys and the quebradas (e.g. on the lower slopes of El Misti) may also remain at risk in case of heavy rainfall. 


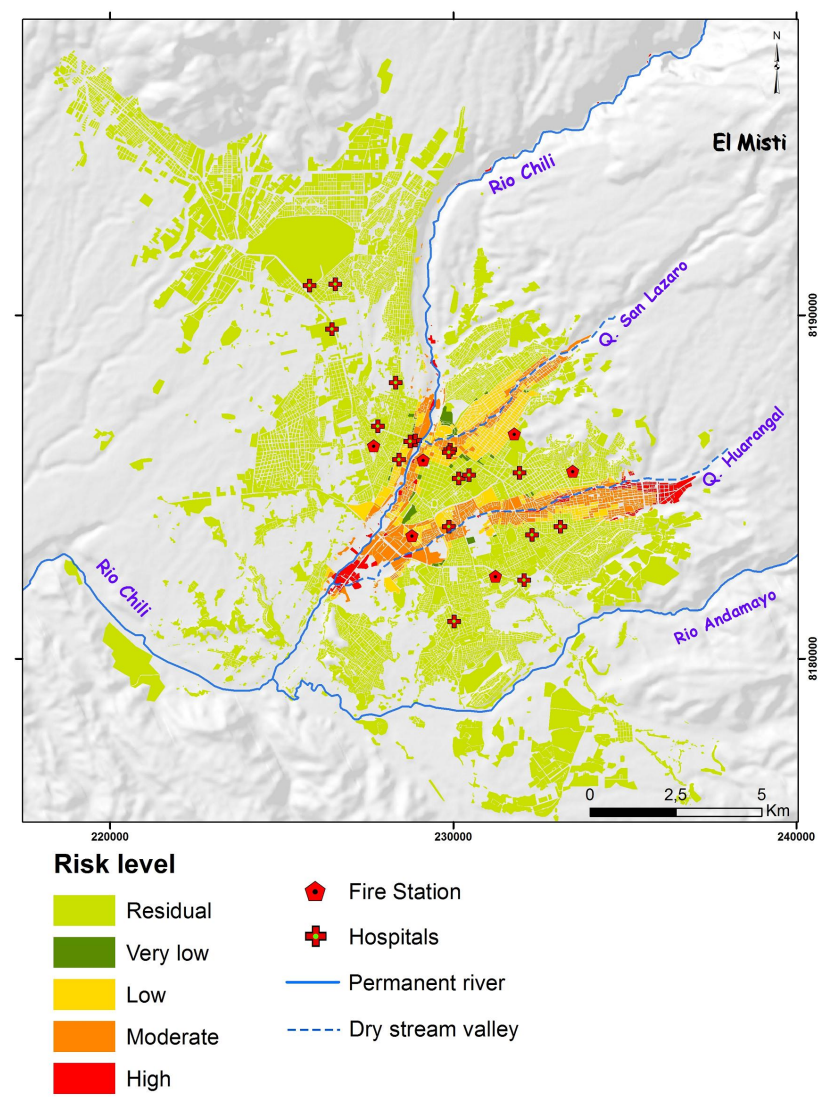

Fig. 13. Areas prone to lahar and flood risk in Arequipa. Areas prone to lahar and flood risk have been divided into five classes according to Table 8 (LRL). The scale of original data (city block) ensures a high level of precision. The figure takes into account flood and lahar risk only; hence only the river and Quebrada channels are at risk.

\subsection{Recommendations for disaster prevention and risk management in Arequipa}

The detailed risk maps (Figs. 13 and 14) can be compared with existing documents such as the official risk map for heavy rainfall and floods (Municipalidad Provincial de Arequipa, 2010). While the strength of land-use planning lies in identifying riverbanks, bridges and dikes at risk, the official map does not provide socio-economic data related to risk. Our approach offers precise information at the city-block and district scale, identifying areas that need to receive attention on a priority basis because their inhabitants are at high risk. The maps clearly indicate that existing official maps and documents should be updated. In addition to the nature and consequences of natural hazards, emergency plans must also consider the population's vulnerability in addition to hazard levels. The current encroachment of the city towards more hazardous areas (Fig. 1) makes this task a high priority, because new settlements near the boundaries of the city are

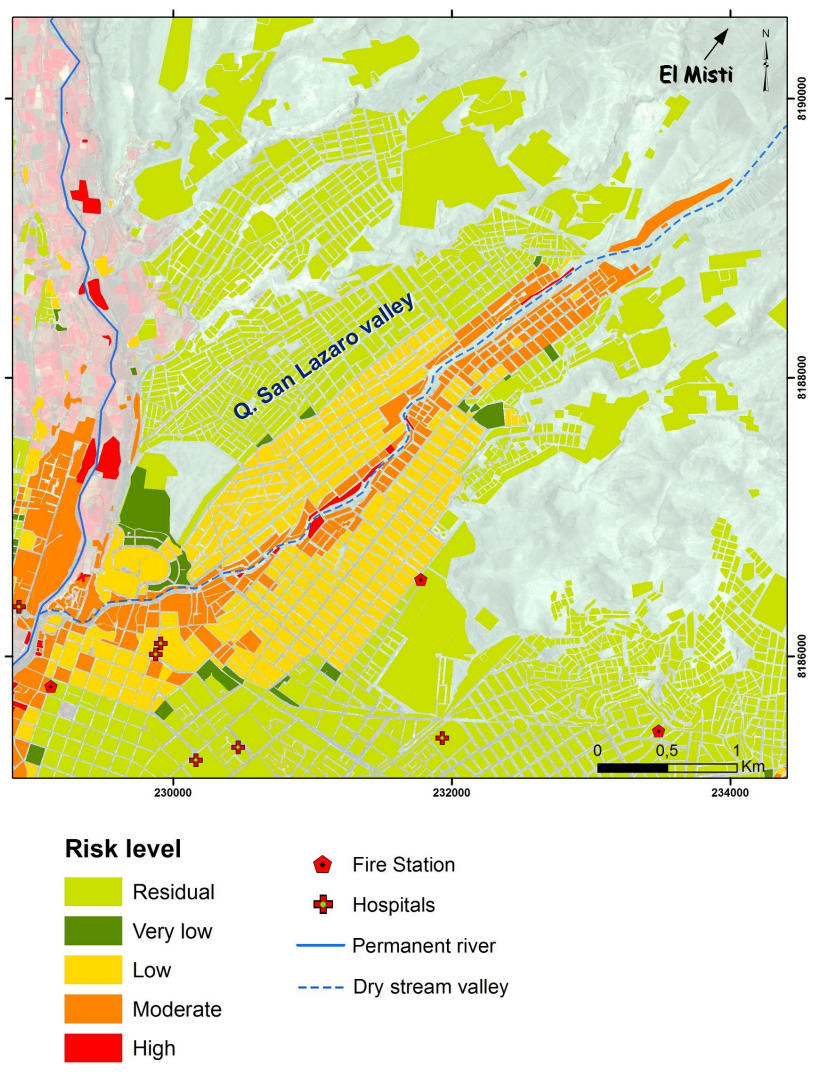

Fig. 14. Areas prone to lahar risk in the Quebrada San Lazaro; this map is an enlargement of Fig. 13.

poorly built and do not have any access to basic facilities in the case of an emergency.

Based on risk maps provided in this study and lessons gained from the management of the recent Ubinas eruption (Rivera et al., 2010), five categories of prevention planning measures can be recommended:

1. Prohibit any further construction on El Misti's southwestern flanks within $10 \mathrm{~km}$ and quebradas within 15 $\mathrm{km}$ of the summit. The municipal ordinance N.658 (15 November 2010), which relies on the volcanic-hazardzone map published by several research institutes in 2007 (Mariño et al., 2007), should be enforced in practice: new settlements may not be established in the flood- and lahar-prone areas, i.e. river channels, low terraces, and on steep slopes. Even after the heavy rainfall in February 2011 and its aftermath on Arequipa's suburbs, many inhabitants reconstructed their houses in the most dangerous areas (e.g. Quebrada Huarangal). The ravines are also used for disposal of garbage and other waste, notably contributing to increased flood volume and impacts. 
2. Plan and develop shelters outside the principal valleys at risk (Río Chili, Qda. San Lazaro and Qda. Huarangal) delineated in Fig. 10c. Two categories of shelters can be planned: (i) shelters in the city which are more than $15 \mathrm{~km}$ from the volcano summit, $0.5 \mathrm{~km}$ from the most threatened quebradas and $1 \mathrm{~km}$ away from the Río Chili bed; and (ii) shelters outside the city area which are at least $25 \mathrm{~km}$ from the volcano summit. In addition, the Municipality should encourage future constructions in the south-eastern part of Arequipa's oasis (i.e. the area of Quequeña and Yarabamba villages), as these areas are sheltered from most of the volcano's impacts. The paved road in this locality (i.e. the road to the Chapi sanctuary) can be used as an evacuation road southward towards the Río Tambo valley, which connects with the Panamericana Road via a bridge upstream of the town of El Fiscal.

3. Expand programmes for public awareness and preparedness of the population at risk near quebradas and along the Río Chili valley. Such programmes, which were started in 2009 in pilot areas, should involve workshops, dissemination of leaflets and evacuation practice conducted by Civil Protection, INGEMMET and the Municipality of Arequipa. The maps (Figs. 13 and 14) can be used directly by Civil Protection in order to set up preventive measures and to organize crisis relief when necessary.

4. Ensure the city's power supply system by establishing a back-up transmission line with the Peruvian coastal power grid. This project would provide electricity to major parts of the city even if the current power plant is flooded, or if the power supply facilities and dams fail due to a large flood or lahar through the Río Chili canyon.

5. Provide a back-up water supply in case the intake canals located near the power supply facilities in the Río Chili canyon are damaged. SEDAPAR should survey additional water wells, sources and reservoirs in order to provide water to the city in case of a disruption. The company could also prepare a contingency plan to bring in (by truck or plane) an emergency supply of potable water from neighbouring regions not affected. Until now, the lack of water tanks in the city centre remains a crucial issue.

\section{Conclusions}

The city of Arequipa is highly exposed to natural hazards: subduction- and fault-related earthquakes, eruptions from the historically active El Misti volcano, debris flows, raintriggered hyperconcentrated streamflows and flash floods, and landslides from the steep Río Chili canyon walls. Among those dangers, flash floods and lahars represent a latent threat because at least 50000 people live in or around exposed valleys in precarious conditions. In such a hazardous environment, outlining hazard zones and improving risk management is crucial to better protect the population.

This research offers a reliable tool to define areas at risk by taking into account three main parameters: lahar and flood hazard, the population's vulnerability (through the buildings' conditions and living standards) and more specifically the population's exposure. To fully evaluate the exposure, the access to, or relative isolation from, strategic resources such as safe areas located on the highest terraces, hospitals, fire stations and drinking water has been considered. This approach takes into account the distance to access these resources from each city block. The combination of these criteria emphasizes the contrasting vulnerabilities between the city centre and the outskirt areas. The former concentrates the activities while the latter hosts a poor population living in risky conditions. Therefore, most areas at risk are directly located in the quebradas and in the new "illegal" settlements located on the flanks of El Misti. For instance, districts located in the upper reach of the valleys (Qda. San Lazaro and Qda. Huarangal) have a high exposure to natural hazards but have limited access to vital resources.

The consequences of floods and lahars can be reduced provided there is a timely evacuation and the population has easy access to vital resources such as hospitals and dispensaries, water tanks and shelters. This research can provide a guideline to modify and update the current official risk management plans and to therefore reduce the exposure to lahar risk. Awareness actions performed by Civil Protection teams can be targeted more efficiently using the new risk mapping as an education tool for understanding the combined effects of natural hazards and the root causes of the exposure of the city to risks. However, the people's actual behaviour in case of a crisis remains difficult to take into account. For instance, newcomers located on the fringes of the city are migrants who are unaware of flood risk in the otherwise dry ravines. Despite the destruction caused by heavy rainfall in February 2011, many people returned to the same areas that were devastated only a few months before. Therefore, significant specific actions such as the removal of the houses located in the quebradas and the cleaning of the ravines of trash and rubbish would constitute a strong signal for the strict implementation of risk-reduction plans adopted by the Municipality and regional government of Arequipa.

This multidisciplinary approach needs to continue in the near future in order to (1) define precisely the potential effects of volcanic flow and flash-flood hazards and improve the delineation of the districts that need to be protected; (2) evaluate monetary loss impacts in the case of lahar and floods; (3) collect additional and updated socio-economic 
parameters (although difficult to obtain, this type of data will improve the quality and usefulness of risk mapping); (4) conduct more simulation exercises for lahar crises using more-precise hazard- and risk-zone maps; and (5) evaluate precisely consequences in terms of evacuation and access to resources. This work should be jointly carried out with simulations led by Civil Protection.

Acknowledgements. This article received the support of the French National Research Agency within the project "Laharisk" (ANR-09-RISK-005). We thank our colleagues involved in the project "Laharisk" funded by the French ANR RiskNat (20102012): M. Willinger (University of Montpellier1), R. Kast (French Institute of Pondicherry), C. Heitz (University of Strasbourg), M. A. Bchir (University of Strasbourg), R. Vargas-Franco (ITC, the Netherlands), D. Fabre (Cnam, Paris), A. Talon (Polytech, Clermont), and C. Pallares (University of Paris XI). We thank C. Magill for her suggestions that greatly improved an early version of this paper and R.I. Tilling for a thorough review. We acknowledge the support of the Civil Protection office in Arequipa, as well as all our colleagues involved in risk management. This manuscript is CLERVOLC contribution No. 56.

Edited by: P. Reichenbach

Reviewed by: D. K. Chester and R. I. Tilling

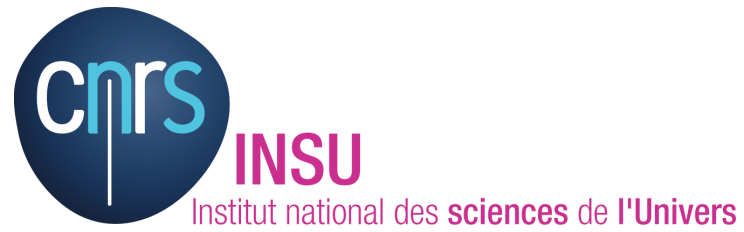

The publication of this article is financed by CNRS-INSU.

\section{References}

Blaikie, P., Cannon, T., Davis, I., and Wisner, B.: At Risk: Natural Hazards, People's Vulnerability, and Disasters, New York, NY, Routledge, 2nd Edn., 464 pp., 2004.

Cannon, T.: A hazard need not a disaster make: vulnerability and the causes of "natural" disasters, in: Natural Disasters: Protecting Vulnerable Communities, Thomas Telford, edited by: Merriman, P. A. and Browitt, C. W. A., London, 591 pp., 1993.

Cobeñas, G., Thouret, J.-C., Bonadonna, C., and Boivin, P.: The c. 2030 yr. BP-old Plinian eruption of El Misti, Peru: characteristics of the fallout and pyroclastic flows, and eruption dynamics, Volcanol. Geotherm. Res., 241-242, 106-120, 2012.

Cutter, S. L., Boruff, B. J., and Shirley, W. L.: Social Vulnerability to Environmental Hazards, Social Sci. Quarterly, 84, 242-261, 2003.

De La Cruz-Reyna, S., Meli, R. P., and Quaas, R. W.: Volcanic crises management, edited by: Sigurdsson, H., Encyclopedia of Volcanoes, San Diego, Academic Press, 1199-1214, 2000.

Delaite, G., Thouret, J.-C., Sheridan, M., Labazuy, Ph., Stinton, A., Souriot, T., and Van Westen, C.: Assessment of volcanic hazards of El Misti and in the city of Arequipa, Peru, based on GIS and simulations, with emphasis on lahars, Z. Geomorphol., N. F., 140, 209-231, 2005.

D'Ercole, R. and Metzger, P.: Vulnerabilidad del Distrito Metropolitano de Quito, Colección Quito Metropolitano, MDMQ-IRD, Quito, Ecuador, 496 pp., 2004.

González, D. and Díaz, R.: Ser verde en 2009 es como estar online en 1999, América Economia, 7728, 22-25, 2008.

Harpel, C. J., de Silva, S., and Salas, G.: The 2 ka Eruption of Misti Volcano, Southern Peru - The Most Recent Plinian Eruption of Arequipa's Iconic Volcano, Geological Society of America, Special Paper 484, 1-72, 2011.

Hollnagel, E.: Resilience: The challenge of the unstable, in: Resilience Engineering: concepts and precepts, edited by: Hollnagel, E., Woods, D. D., and Leveson, N., Ashgate, Burlington (VT), 9-17, 2006.

Hufschmidt, G., Crozier, M., and Glade, T.: Evolution of natural risk: research framework and perspectives, Nat. Hazards Earth Syst. Sci., 5, 375-387, doi:10.5194/nhess-5-375-2005, 2005.

Keys, H. J. R.: Lahars of Ruapehu Volcano, New Zealand: risk mitigation, Ann. Glaciol., 45, 155-162, 2007.

Künzler, M., Huggel, C., and Ramirez, J. M.: A risk analysis for floods and lahars: case study in the Cordillera Central of Colombia, Nat. Hazards, 64, 767-796, 2012.

Lavigne, F.: Lahar hazard micro-zonation and risk assessment in Yogyakarta city, Indonesia, GeoJournal, 49, 173-183, 1999.

McEntire, D. A.: Triggering agents, vulnerabilities and disaster reduction: towards a holistic paradigm, Disaster Prevention and Management, 10, 89-196, 2001.

Macedo, L.: Aportes del INGEMMET en el 1er simulacro de evacuación por erupción volcánica en Arequipa: Las geociencias y su responsabilidad social, INGEMMET, 42 pp., 2009.

Macedo, L.: Preparación ante emergencias de origen volcánico, Una guía para la reducción del riesgo volcánico en el Perú, Geodinámica e Ingeniería Geológica, INGEMMET, Boletín No. 49, Serie C, 125 pp., 2012.

Mariño, J., Rivera M., Cayca, L., Thouret J.-C., Macedo, L., Salas, G., Siebe, C., Tilling, R. I., Sheridan, M., Chávez, A., and Zúñiga, S.: Mapa de Peligros del Volcán Misti, Instituto Geológico Minero y Metalúrgico. Lima, Perú, (Main map, scale 1:50 000; 3 inset maps at variable scales, 2007.

Martelli, K. M.: The physical vulnerability of urban areas facing the threat of inundation from lahars and floods: application to the city of Arequipa, Peru, Unpublished Ph.D thesis, Laboratoire Magmas et Volcans, Université Blaise Pascal, 15 September 2011, 345 pp., 2011.

Martelli, K. M., Thouret, J.-C., and Vargas-Franco, R.: Physical Vulnerability and Quantitative Risk Assessment of Housing and Infrastructure from the Potential Impacts of Volcanic Mass Flows in Arequipa, Peru. Cities on Volcanoes, COV6 Tenerife, 31 May - 4 June 2010, Abstract and Poster, 2010.

Mechler, R.: Natural Disaster Risk Management and Financing Disaster Losses in Developing Countries, Verlag Versicherungswirtschaft GmbH, Karlsruhe, Germany, 317 pp., 2004.

Municipalidad Provincial de Arequipa: Plan Director de Arequipa Metropolitana 2002-2015, 2002.

Municipalidad Provincial de Arequipa: Plan de contingencia ante precipitaciones pluviales en la Provincia de Arequipa 2010-2011, http://www.muniarequipa.gob.pe/descargas/ emergencia/plan.pdf, 2010. 
Peck, H.: Reconciling supply chain vulnerability, risk and supply chain management, International Journal of Logistics: Research and Applications, 9, 127-142, 2006.

Pierson, T. C.: Hyperconcentrated flow - transitional process between water flow and debris flow, in: Debris flow hazards and related phenomena, edited by: Jakob, M. and Hunger, O., Springer, 159-202, 2005

Pinto da Cunha, J.: Urbanización, Redistribución Espacial de la Población y Transformaciones Socioeconómicas en América Latina, Santiago: CEPAL, Serie Población y Desarrollo, 30, 2002.

Rivera, M., Thouret, J.-C., Mariño, J., Berolatti, R., and Fuentes, J.: Characteristics and management of the 2006-2008 volcanic crisis at the Ubinas volcano (Peru), J. Volc. Geoth. Res., 198, 19-34, 2010.

Rolandi, G.: Volcanic hazard at Vesuvius: Revising the current emergency plan, J. Volc. Geoth. Res., 189, 347-362, 2010.

Santoni, O.: Etude de la vulnérabilité de la ville d4arequipa, Pérou, vis à vis du volcan El Misti, au moyen d'un SIG, Rapport de Master 2 Pro Mention TSAD Spécialité SIIG3T, 51 pp., 2011.

Schneiderbauer, S. and Ehrlich, D.: Risk, hazard and people's vulnerability to natural hazards: A review of definitions, concepts and data, Joint Research Centre, European Commission, EUR21410, 2004.

Smith, K. and Petley, D. N.: Environmental Hazards: Assessing Risk and Reducing Disasters, London and New York, Routledge, 383 pp., 2009.
Tatham, P. and Kovacs, G.: The Humanitarian Supply Network in Rapid Onset Disasters, NOFOMA Proceedings, Reykjavik, Iceland, 2007.

Thouret, J.-C.: Aléas et risques volcaniques: mieux comprendre pour prévoir et mieux gérer pour durer, Ann. Géogr., 627-628, 503-523, 2002.

Thouret, J.-C. and Laforge, C.: Hazard Appraisal and Hazard-Zone Mapping of Flooding and Debris Flowage in the Rio Combeima Valley and Ibague City, Tolima Department, Colombia, GeoJournal, 34, 407-413, 1994.

Thouret, J.-C., Suni, J., Finizola, A., Fornari, M., Legeley-Padovani, A., and Frechen, M.: Geology of El Misti volcano near the city of Arequipa, Peru, Geol. Soc. Am. Bull., 113, 1593-1610, 2001.

Vallance, J. W.: Lahars, H., in: Encyclopedia of volcanoes, edited by: Sigurdsson, San Diego, Academic Press, 601-616, 2000.

Vargas-Franco, R., Thouret, J.-C., Delaite, G., van Westen, C., Sheridan, M. F., Siebe, C., Mariño, J., Souriot, T., and Stinton, A.: Mapping and Assessing Volcanic Hazards and Risks in the city of Arequipa, Peru, based on GIS techniques, in: Stratigraphy and Geology of volcanic areas, edited by: Groppelli, G. and Viereck-Goette, L., Geol. Soc., Am. Special Publication SPE464, 265-280, 2010.

Zanchetta, G., Sulpizio, R., Pareschi, M. T., Leoni, F. M., and Santacroce, R.: Characteristics of May 5-6, 1998, volcaniclastic debris flows in the Sarno area (Campania, Southern Italy): relationships to structural dame and hazard zonation, J. Volc. Geoth. Res., 133, 377-393, 2004. 